Article

\title{
Does the Use of an Intercropping Mixture Really Improve the Biology of Monocultural Soils?-A Search for Bacterial Indicators of Sensitivity and Resistance to Long-Term Maize Monoculture
}

\author{
Agnieszka Wolińska ${ }^{1, *} \mathbb{0}$, Anna Kruczyńska ${ }^{1} @$, Jacek Podlewski ${ }^{2}$, Andrzej Słomczewski ${ }^{2}$, \\ Jarosław Grządziel $^{3}$ (D), Anna Gałązka ${ }^{3}$ (D) and Agnieszka Kuźniar ${ }^{1}$ (D) \\ 1 Department of Biology and Biotechnology of Microorganisms, The John Paul II Catholic University of Lublin, \\ Konstantynów St. 1 I, 20-708 Lublin, Poland; anna.kruczynska@kul.pl (A.K.); agnieszka.kuzniar@kul.pl (A.K.) \\ 2 Potulicka Foundation Economic Center, Wojnowo 5, Sicienko, 86-014 Bydgoszcz, Poland; \\ jpodlewski@fundacjapotulicka.pl (J.P.); aslomczewski@fundacjapotulicka.pl (A.S.) \\ 3 Department of Agriculture Microbiology, Institute of Soil Science and Plant Cultivation, Czartoryskich 8 Str., \\ 24-100 Puławy, Poland; jgrzadziel@iung.pulawy.pl (J.G.); agalazka@iung.pulawy.pl (A.G.) \\ * Correspondence: agnieszka.wolinska@kul.pl; Tel.: +48-81454-54-56
}

Citation: Wolińska, A.; Kruczyńska, A.; Podlewski, J.; Słomczewski, A.; Grządziel, J.; Gałązka, A.; Kuźniar, A. Does the Use of an Intercropping Mixture Really Improve the Biology of Monocultural Soils?-A Search for Bacterial Indicators of Sensitivity and Resistance to Long-Term Maize

Monoculture. Agronomy 2022, 12, 613 https://doi.org/10.3390/ agronomy12030613

Academic Editor: Helena Freitas

Received: 20 December 2021

Accepted: 26 February 2022

Published: 28 February 2022

Publisher's Note: MDPI stays neutral with regard to jurisdictional claims in published maps and institutional affiliations.

Copyright: (C) 2022 by the authors. Licensee MDPI, Basel, Switzerland. This article is an open access article distributed under the terms and conditions of the Creative Commons Attribution (CC BY) license (https:// creativecommons.org/licenses/by/ $4.0 /)$

\begin{abstract}
The choice of appropriate agricultural practices has a significant impact on soil quality, crop productivity, or soil microbial community. Ten representative soil samples were collected in Wierzchucin Królewski (Kujawsko-Pomorskie Province, NW Poland), an agricultural area belonging to the Potulicka Foundation Group. The cropping systems included a maize monoculture grown continuously for over 30 years and an intercropping mixture (Gorzow mixture) applied in 2020. The study aimed to determine the effect of the intercropping system on the quality and biodiversity of the studied soils and to identify bacterial indicators of sensitivity and resistance to long-term maize monoculture. Therefore, in this study, the impact of the intercrop mixture application on the chemical and biological soil properties and on the diversity of the bacterial community was evaluated by amplifying the 16S rRNA gene sequences and indicators of sensitivity and resistance to long-term maize monoculture were recommended. The results showed that intercropping had a positive effect on soil features and increased the richness and diversity of soil bacteria at the taxonomic level of genera compared to the maize monoculture. Massilia and Haliangium were proposed to be bacterial indicators of sensitivity, while Sphingomonas was recommended to be an indicator of resistance to long-term maize monoculture. Overall, our results evidenced that using an intercropping system may be a sustainable agricultural practice in this area and in north-western Poland.
\end{abstract}

Keywords: intercropping mixture; maize monoculture; bacterial indicators of sensitivity; bacterial indicators of resistance; agricultural practice; soil microbial community; $16 \mathrm{~S}$ rRNA

\section{Introduction}

Maize is one of the most profitable and promising field crops. At present, the farmers' growing interest in maize cultivation is related to its high productivity and versatility of use. Maize is a valuable fodder crop used in the nutrition for a wide range of livestock; additionally, this industrial crop is increasingly being applied in the food industry and as an energy source [1]. In many countries, e.g., China [2,3], Japan [4], Germany [5], England [6], and Poland [7], the traditional cropping system has been replaced by conventional agricultural practices that have a significant impact on crop productivity, soil quality, or the soil microbial community [8,9]. Nevertheless, many literature sources have reported that these practices may cause a decrease in soil organic matter (SOM), loss of soil biodiversity, and an increase in soil erosion and degradation [9-13]. SOM, which plays a leading role in the physical, chemical, and biological properties of soils, is an important indicator of 
soil quality [11]. Soil microbes, which are responsible for, e.g., nutrient cycling and crop productivity, are the living part of SOM [12]. The changes in their diversity caused by agricultural practices are often substantially less pronounced in arable soils than in natural ecosystems soils [13]. Noteworthy, soil microbial activity is an important indicator of soil fertility, and is one of the key biological components of soil $[14,15]$.

Monoculture, i.e., cultivation of the same crops in the same place each year, deprives the soil of nutrients and limits its ability to support healthy plant growth over time [16]. Hence, farmers are forced to use chemical fertilizers, which in turn disrupt the natural composition of the soil and lead to further nutrient depletion. Monoculture also causes the spread of pests and diseases, which must be controlled using even greater amounts of chemicals [17].

One alternative to improve the quality of monoculture soils is the use of intercrop mixtures. Intercropping (IC) involves the cultivation of several (two or more) crops simultaneously in the same field [16-19]. IC is a sustainable practice applied in modern agricultural production systems in Poland and worldwide $[20,21]$. There are different types of intercropping: row, strip, relay, temporary, mixed, conservation, alley, trap, deterrent, and push-pull; they are equally effective in improving soil quality [22]. Many advantages of the intercropping system are known, but the greatest benefit is the achievement of a relatively higher yield due to the more efficient use of available growth resources while using a mixture of crops with a different rooting ability, canopy structure, height, and nutrient requirements [23]. Literature sources also report that intercropping significantly improves soil fertility through biological nitrogen fixation by legumes, soil conservation through a denser crop distribution than in monoculture, and higher resistance to lodging in crops susceptible to this phenomenon [24]. In addition, the use of an intercropping mixture promotes the improvement of forage plants, reduction of pests and diseases, and promotion of biodiversity [24]. Nevertheless, the intercropping system has disadvantages, e.g., competition for light, water, and nutrients, allelopathic effects, and practical problems that may result from failure to adapt agricultural practices to the intercropping system [24,25].

Climate change has a major impact on crop quality and productivity [26]. Hot weather, droughts, or excessive rainfall and consequent floods often lead to crop failure and reduction in yield [26]. Therefore, in order to draw reasonable conclusions, this study was based on three terms of the growing season (spring, summer, autumn).

This paper aims to answer the question about intercrop mixtures, i.e., whether their application really supports the biological properties of monoculture soils. We selected two biological factors, dehydrogenase and respiration activities, to measure soil fertility and monitored their response to the intercropping mixture application in a long-term maize monoculture field. There are several studies on the use of intercropping mixtures; however, only a few have attempted to investigate the effects of intercrops on soil physical and chemical properties and the diversity and composition of the soil microbial community [27-30]. Therefore, this paper focuses on comparing the chemical and biological properties of the studied soils (under the intercropping mixture and the maize monoculture) and, most importantly, examining the variation in bacterial biodiversity during three terms of the vegetation season, with emphasis on indicators of sensitivity and resistance to long-term maize monoculture. Based on literature data, we hypothesized that intercropping (i) might have distinct effects on the soil bacterial community structure and diversity, and (ii) should improve soil biological quality compared to long-term monocultures.

\section{Materials and Methods}

\subsection{Description of the Study Area and Soil Sampling Procedure}

The study area was located in Wierzchucin Królewski village (Kujawsko-Pomorskie Province, NW Poland) on a site belonging to the Potulicka Foundation Group (Figure 1). 


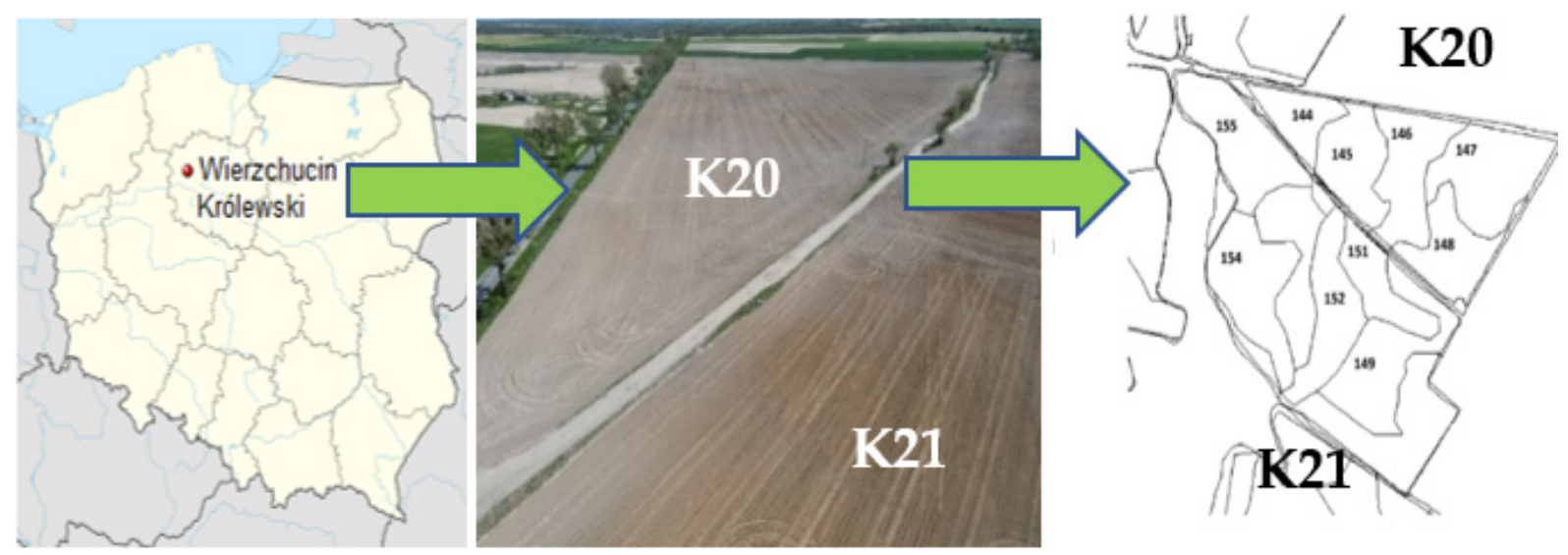

Figure 1. Location of the study area with a photograph of the two studied fields and separated rasters.

The agricultural area held by the Potulicka Foundation covers approx. 6130 ha of farmland and, importantly, over $60 \%$ of the crop is maize grown for forage and grain. More than $95 \%$ of the Potulicka Foundation agricultural area has been mapped using GPS technology, which is extremely important due to the irregular shapes of the fields and the variability (heterogeneity) of the fields in terms of their nutrient contents (Figure 1).

Two neighboring fields were selected for this study: K20, on which the Gorzow mixture (intercropping mixture) was sown to improve soil quality after maize monoculture in 2020, and K21, on which the long-term (more than 30 years) monoculture cultivation was continued (Figure 1). Importantly, the Gorzow mixture was sown in the main burn in spring to break the maize monoculture and improve soil properties. The mixture was harvested as green matter for cattle feed (two swaths) and plowed in autumn as green manure.

Field K20 $\left(53.296^{\circ} \mathrm{N}, 17.790^{\circ} \mathrm{E}\right)$, covering an area of $15 \mathrm{ha}$, is a long-term maize monoculture, but in 2020 it was sown with the Gorzow mixture (composed of perennial ryegrass, incarnate clover, and winter vetch) to improve the soil structure. In turn, field K21 $\left(53.294^{\circ} \mathrm{N}, 17.788^{\circ} \mathrm{E}\right)$, covering an area of $24 \mathrm{ha}$, is a perennial maize monoculture, but it has never been sown with the intercropping mixture. Importantly, fertilization was applied in April 2020 (after soil sampling but before maize sowing) only in field K21, whereas K20 was not fertilized in 2020). Potassium (K) fertilization was carried out at a dose of $100 \mathrm{~kg} \mathrm{ha}{ }^{-1}$ of $\mathrm{K}$ salt with $60 \% \mathrm{~K}_{2} \mathrm{O}$, whereas nitrogen $(\mathrm{N})$ fertilization in the form of urea $46 \% \mathrm{~N}$ was applied at a rate ranging from 150 through 175 to $200 \mathrm{~kg} \mathrm{ha}^{-1}$, depending on the yield potential in each $\mathrm{K} 21$ raster.

From each field, five separate rasters (each about $3 \mathrm{ha}$ ) were selected, and soil samples were taken from the surface layer $(0-20 \mathrm{~cm})$ according to Polish Standard PN-ISO 10381-61998 three times a year: in spring (March 2020), summer (June 2020), and autumn (November 2020). The soil samples were collected randomly from 20-30 sites of each raster. Sampling was carried out in an automated manner using the IT system available on the Potulicka Foundation farms, which allowed precise sampling from the same locations on each date. In laboratory conditions, the soil materials were sieved through a 2-mm sieve and stored in a refrigerator $\left(4^{\circ} \mathrm{C}\right)$ until chemical analysis, whereas DNA extraction and determination of biological activities were performed immediately after the sampling.

\subsection{Soil Chemical Features}

The $\mathrm{pH}$ and redox potential (Eh) values were determined from a 2:1 soil suspension prepared in distilled water using an automatic multifunctional potentiometer (Hach, Lange, Glasch, Germany). To determine the total organic carbon (TOC) concentration, an automatic carbon analyzer TOC-V $\mathrm{CSH}_{\mathrm{H}}$ SSM 5000A (Shimadzu, Kyoto, Japan) was used according to the procedure described by Wolinska et al. [16]. The soil moisture was determined with the gravimetric method $\left(24 \mathrm{~h}, 105^{\circ} \mathrm{C}\right)$. All measurements were taken in triplicate. 


\subsection{Soil Biological Activities}

Respiration activity (RA) analyses were performed on a gas chromatograph (GC, Varian C-3800) equipped with a flame ionization detector (FID) and a thermal conductivity detector (TCD). Briefly, $10 \mathrm{~g}$ of soil was weighed into sterile dark glass bottles (60 mL) (in 3 independent replicates), and the bottles were sealed with a rubber stopper and an aluminum cap. The samples were incubated at $20^{\circ} \mathrm{C}$ for 7 days. Next, the chromatographic analysis was performed [31]. The respiration rate was related to changes in the content of released $\mathrm{CO}_{2}\left(\mathrm{mg} \mathrm{kg}^{-1}\right.$ d.w. $\left.\mathrm{d}^{-1}\right)$.

Dehydrogenase activity (DA) was determined with the method developed by Casida et al. [32], in which a suitable substrate (2.3.5-triphenyltertazolium chloride, TTC) introduced into the soil is transformed by oxidoreductive enzymes (dehydrogenases) into a product quantified easily with the colorimetric method. Shortly, a soil sample $(6 \mathrm{~g})$ was mixed with $120 \mathrm{mg} \mathrm{CaCO}, 1 \mathrm{~mL} 1 \%(w / v)$ TTC, and $4 \mathrm{~mL}$ of distilled water and incubated for $20 \mathrm{~h}$ at $30 \pm 1{ }^{\circ} \mathrm{C}$ (Heraens Instruments). Enzymatic activity was quantified by reference to a calibration curve constructed with data obtained by incubating TTC standards in the conditions described above and was expressed in $\mu \mathrm{g} \mathrm{TPF} \mathrm{g}^{-1} \mathrm{~min}^{-2}$ [31]

\subsection{Next Generation Sequencing and Bioinformatic Analysis}

For DNA extraction (0.35 g soil), the commercial DNeasy Power Lyzer Power Soil Kit (Qiagen, Hilden, Germany) was used, and the isolation was performed according to the manufacturer's Quick-Start Protocol (Qiagen Group, Germantown, MD, USA). Three independent replicates of DNA isolation were performed for each of the soil rasters. Metabarcoding or $16 \mathrm{~S}$ rRNA community profiling analysis was performed based on the hypervariable V3-V4 region of the 16S rRNA gene [33]. Primers (341f, 785r) were applied for both the amplification of the selected region and the preparation of the library $[33,34]$. The PCR reaction was carried out using Q5 Hot Start High-Fidelity 2X Master Mix (New England Biolabs Inc., Ipswich, MA, USA) as described by Wolińska et al. [33,35]. After receiving positive results of PCR, triplicate samples of soil DNA were pooled as recommended by Kuźniar et al. [36].

Next Generation Sequencing (NGS) was performed by Genomed S.A. (Warsaw, Poland) on a MiSeq sequencer (Illumina, San Diego, CA, USA) in paired-end (PE) technology, $2 \times 300 \mathrm{nt}$, using an Illumina v2 kit (San Diego, CA, USA).

The preliminary analysis of the data obtained was carried out with MiSeq Reporter (MSR) v2.6 software (Illumina, San Diego, CA, USA). A detailed description of the subsequent steps is included in our previous paper [33]. The sequences were clustered based on a 97\% similarity threshold [33].

Bioinformatic analyses were performed in R v4.1 using DADA2 v1.18 [37], and sequences were classified using the DECIPHER package v2.20 [37] based on the GreenGenes v13_8 reference sequence database [38]. The results are presented as a percent of the relative abundance of identified sequences at the selected taxonomy levels (phyla, genera). The identified sequences are available under accession number PRJNA725644 (GenBank Database, NCBI: https:/ / www.ncbi.nlm.nih.gov/bioproject/PRJNA725644 (accessed on 28 April 2021)).

\section{Results}

\subsection{Soil Chemical Characteristics}

The basic chemical properties ( $\mathrm{pH}, \mathrm{Eh}, \mathrm{TOC}$, moisture) of the investigated fields (K20intercropping mixture and K21-maize monoculture) varied over different seasons (spring, summer, autumn), as shown in Table 1.

The acidity $(\mathrm{pH})$ of soils where the intercrop mixture was applied (K20-144-K20-148) ranged from 6.07 to 7.90 in spring, from 5.70 to 6.63 in summer, and from 5.99 to 6.94 in autumn. A small difference in $\mathrm{pH}$ was observed in the soils under the long-term maize monoculture (K21-149-K21-155), with values ranging from 5.82 to 7.93 in spring, 5.31 to 6.60 in summer, and 5.84 to 6.99 in autumn. The lower range of the $\mathrm{pH}$ values in the soils with 
the long-term maize monoculture indicates that they were slightly more acidic, with the highest acidity in summer $(\mathrm{pH}=5.31$ for $\mathrm{K} 21-149)$. All soils were well aerated. The highest redox potential (Eh) level was noted in summer (534.57 mV for K20 and $568.03 \mathrm{mV}$ for K21 soils), and its lowest value was recorded in autumn (417.73 mV for K20 and $426.17 \mathrm{mV}$ for K21 soils) in both studied fields. The content of TOC was higher in field K20, where the intercrop mixture was applied (0.32\% in spring, $0.37 \%$ in summer, and $0.47 \%$ in autumn). The highest moisture values in the examined soils were recorded in autumn $(13.35 \%$ for K21-154 and $13.05 \%$ for K20-144), while the lowest value was noted in spring (4.59\% for K20-144 and $6.20 \%$ for K21-149).

Table 1. Basic chemical properties of the fields in different seasons: K20-intercropping mixture and K21-maize monoculture (mean values of three replicates \pm standard deviation level).

\begin{tabular}{|c|c|c|c|c|}
\hline No of Raster & $\mathrm{pH}_{(\mathrm{H} 2 \mathrm{O})}$ & Eh $(\mathrm{mV})$ & TOC (\%) & Moisture (\%) \\
\hline \multicolumn{5}{|c|}{ SPRING } \\
\hline K20-144 & $6.07 \pm 0.04$ & $509.23 \pm 0.12$ & $0.71 \pm 0.01$ & $4.59 \pm 0.07$ \\
\hline K20-145 & $6.07 \pm 0.03$ & $526.50 \pm 0.85$ & $0.82 \pm 0.04$ & $5.89 \pm 0.11$ \\
\hline K20-146 & $7.90 \pm 0.03$ & $493.60 \pm 0.08$ & $0.61 \pm 0.03$ & $7.56 \pm 0.05$ \\
\hline K20-147 & $6.21 \pm 0.03$ & $514.30 \pm 0.16$ & $1.16 \pm 0.04$ & $9.53 \pm 0.08$ \\
\hline K20-148 & $6.07 \pm 0.04$ & $525.60 \pm 0.21$ & $1.34 \pm 0.03$ & $8.92 \pm 0.06$ \\
\hline K21-149 & $6.02 \pm 0.01$ & $514.70 \pm 0.04$ & $0.52 \pm 0.03$ & $6.20 \pm 0.03$ \\
\hline K21-151 & $6.40 \pm 0.01$ & $509.60 \pm 1.60$ & $0.59 \pm 0.03$ & $7.36 \pm 0.06$ \\
\hline K21-152 & $5.82 \pm 0.04$ & $520.20 \pm 0.08$ & $0.56 \pm 0.01$ & $8.51 \pm 0.12$ \\
\hline K21-154 & $6.83 \pm 0.02$ & $507.00 \pm 0.16$ & $0.67 \pm 0.05$ & $7.40 \pm 0.06$ \\
\hline \multicolumn{4}{|c|}{ SUMMER } & $8.41 \pm 0.05$ \\
\hline K20-144 & $6.63 \pm 0.05$ & $534.40 \pm 0.20$ & $0.85 \pm 0.02$ & $10.26 \pm 0.03$ \\
\hline K20-145 & $6.20 \pm 0.05$ & $534.33 \pm 0.26$ & $0.79 \pm 0.02$ & $7.70 \pm 0.06$ \\
\hline K20-146 & $5.95 \pm 0.01$ & $533.86 \pm 0.25$ & $0.77 \pm 0.03$ & $9.13 \pm 0.07$ \\
\hline K20-147 & $6.29 \pm 0.03$ & $527.07 \pm 0.20$ & $0.77 \pm 0.04$ & $10.92 \pm 0.04$ \\
\hline K20-148 & $5.70 \pm 0.02$ & $534.57 \pm 0.05$ & $1.14 \pm 0.04$ & $14.64 \pm 0.08$ \\
\hline K21-149 & $5.31 \pm 0.02$ & $561.53 \pm 0.70$ & $0.71 \pm 0.05$ & $10.24 \pm 0.03$ \\
\hline K21-151 & $5.44 \pm 0.01$ & $567.60 \pm 0.17$ & $0.45 \pm 0.01$ & $9.09 \pm 0.08$ \\
\hline K21-152 & $5.46 \pm 0.01$ & $568.03 \pm 0.59$ & $0.62 \pm 0.04$ & $8.84 \pm 0.06$ \\
\hline K21-154 & $6.08 \pm 0.02$ & $542.67 \pm 0.37$ & $0.77 \pm 0.03$ & $10.73 \pm 0.09$ \\
\hline \multicolumn{4}{|c|}{ AUTUMN } & $10.44 \pm 0.05$ \\
\hline K20-144 & $6.17 \pm 0.03$ & $491.07 \pm 0.28$ & $0.58 \pm 0.02$ & $13.05 \pm 0.06$ \\
\hline K20-145 & $6.60 \pm 0.01$ & $417.73 \pm 3.02$ & $0.52 \pm 0.03$ & $10.88 \pm 0.08$ \\
\hline K20-146 & $6.94 \pm 0.01$ & $424.83 \pm 0.12$ & $0.42 \pm 0.01$ & $12.23 \pm 0.09$ \\
\hline K20-147 & $6.61 \pm 0.03$ & $469.67 \pm 0.25$ & $0.51 \pm 0.05$ & $12.01 \pm 0.11$ \\
\hline K20-148 & $5.99 \pm 0.16$ & $499.13 \pm 0.76$ & $0.87 \pm 0.01$ & $16.32 \pm 0.04$ \\
\hline K21-149 & $5.99 \pm 0.02$ & $496.53 \pm 0.33$ & $0.23 \pm 0.02$ & $11.87 \pm 0.06$ \\
\hline K21-151 & $5.84 \pm 0.01$ & $515.30 \pm 0.21$ & $0.35 \pm 0.01$ & $9.66 \pm 0.03$ \\
\hline K21-152 & $6.33 \pm 0.01$ & $506.57 \pm 0.23$ & $0.36 \pm 0.02$ & $9.61 \pm 0.05$ \\
\hline K21-154 & $6.55 \pm 0.02$ & $484.07 \pm 0.17$ & $0.39 \pm 0.03$ & $13.35 \pm 0.02$ \\
\hline K21-155 & $6.99 \pm 0.04$ & $426.17 \pm 0.12$ & $0.40 \pm 0.03$ & $11.88 \pm 0.03$ \\
\hline
\end{tabular}

\subsection{Soil Biological Activities}

The tested soils differed in their respiration activity (RA) and dehydrogenase activity (DA), as shown in Figures 2 and 3, respectively.

The tested soil rasters were characterized by varying biological activities, even within the same agricultural practice systems. The highest level of RA was recorded in raster K20-145 in autumn (56.56 $\mathrm{mg} \mathrm{CO}_{2} \mathrm{~kg}^{-1} \mathrm{~d}$.w. $\mathrm{d}^{-1}$ ); for comparison, the highest respiration in the monoculture soils was detected in raster $\mathrm{K} 21-153\left(43.98 \mathrm{mg} \mathrm{CO}_{2} \mathrm{~kg}^{-1} \mathrm{~d} . \mathrm{w} . \mathrm{d}^{-1}\right)$. In general, the RA ranged from 13.64 to $56.56 \mathrm{mg} \mathrm{CO}_{2} \mathrm{~kg}^{-1}$ d.w. $\mathrm{d}^{-1}$ for $\mathrm{K} 20$ and was in the range of $14.42-43.98 \mathrm{mg} \mathrm{CO}_{2} \mathrm{~kg}^{-1}$ d.w. $\mathrm{d}^{-1}$ for K21 (Figure 2). 

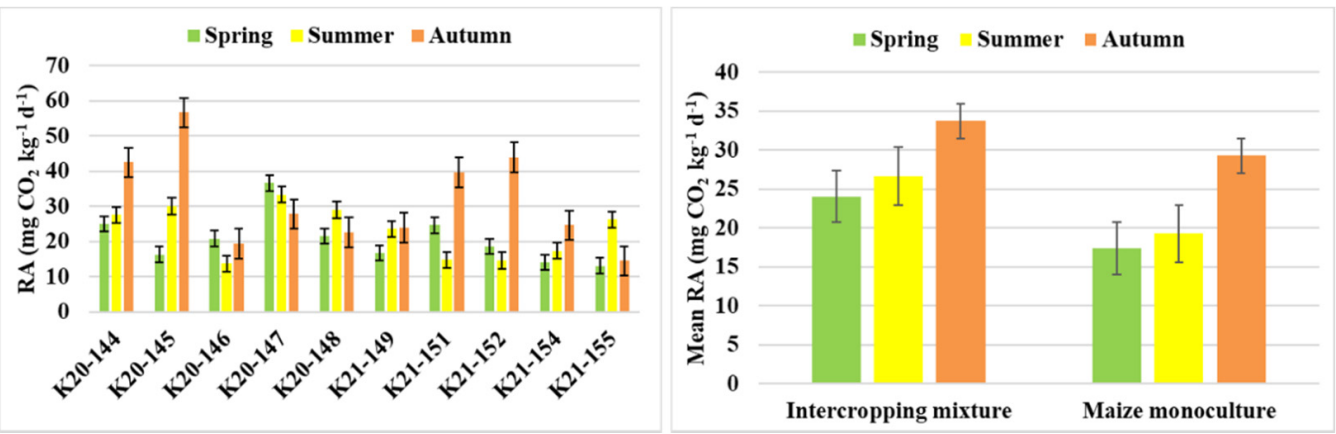

Figure 2. Respiration activity (RA) in the rasters of field K20 under the intercropping mixture and field K21 under the maize monoculture in spring, summer, and autumn.
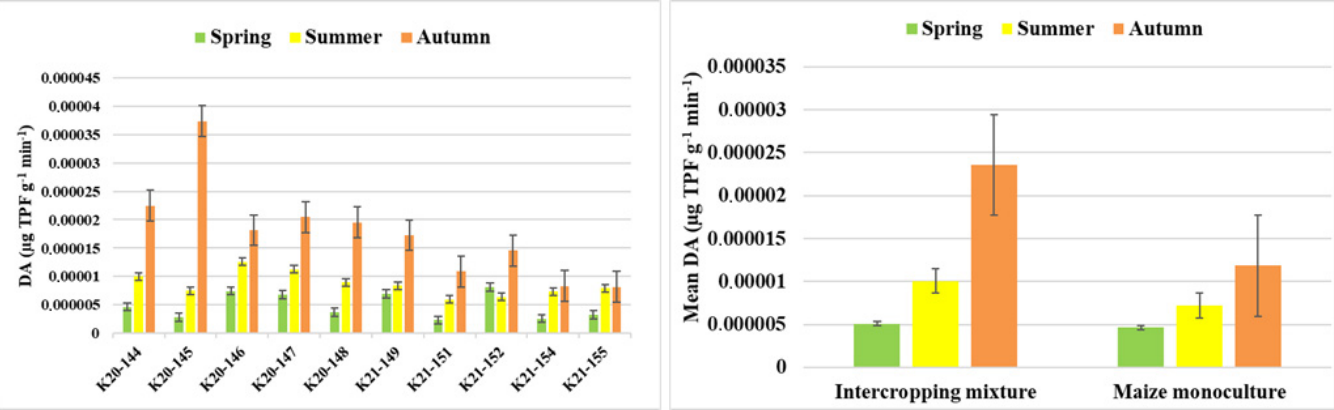

Figure 3. Dehydrogenase activity (DA) in the rasters of field K20 under the intercropping mixture and field K21 under the maize monoculture in spring, summer, and autumn.

It was also evidenced that the season of the year was an important determinant of the recorded RA values. The parameter exhibited the maximal mean values in autumn (33.73 $\mathrm{mg} \mathrm{CO}_{2} \mathrm{~kg}^{-1}$ d.w. $\mathrm{d}^{-1}$ for $\mathrm{K} 20$ and $28.16 \mathrm{mg} \mathrm{CO}_{2} \mathrm{~kg}^{-1}$ d.w. $\mathrm{d}^{-1}$ for K21) and minimal values in spring ( $24.03 \mathrm{mg} \mathrm{CO}_{2} \mathrm{~kg}^{-1}$ d.w. $\mathrm{d}^{-1}$ and $15.52 \mathrm{mg} \mathrm{CO}_{2} \mathrm{~kg}^{-1}$ d.w. $\mathrm{d}^{-1}$ for $\mathrm{K} 20$ and $\mathrm{K} 21$, respectively). This trend was noted both in the Gorzow mixture-sown soils and in those with the long-term maize monoculture (Figure 2). Nevertheless, there were cases in which $\mathrm{RA}$ reached the highest value in spring, and such results were recorded in raster K20-146 (20.8 mg CO $\mathrm{kg}^{-1}$ d.w. $\mathrm{d}^{-1}$ ) or K20-147 (36.59 $\mathrm{mg} \mathrm{CO}_{2} \mathrm{~kg}^{-1}$ d.w. $\left.\mathrm{d}^{-1}\right)$ and even in summer in K20-148 (28.97 mg CO $\mathrm{kg}^{-1}$ d.w. $\left.\mathrm{d}^{-1}\right)$ and $\mathrm{K} 21-155\left(26.19 \mathrm{mg} \mathrm{CO} \mathrm{kg}^{-1}\right.$ d.w. $\left.\mathrm{d}^{-1}\right)$. Importantly, compared to field K20, the RA value in field K21 was approx. 1.2-fold, 1.5-fold, and 1.55-fold lower in autumn, summer, and spring, respectively.

The application of the intercropping mixture contributed to an increase in DA (Figure 3).

The highest DA value was recorded during autumn in raster K20-145 $\left(3.73 \times 10^{-5} \mu \mathrm{g} \mathrm{TPF}^{-1} \mathrm{~min}^{-2}\right)$. It was substantially higher than the maximum DA determined simultaneously for raster K21-149 $\left(1.73 \times 10^{-5} \mu \mathrm{g} \mathrm{TPF}{ }^{-1} \mathrm{~min}^{-2}\right)$. As in the case of RA, the mean values of DA indicated dependence of the parameter on the season (Figure 3). In both fields, K20 and K21, the highest DA level was noted in autumn $\left(2.36 \times 10^{-5} \mu \mathrm{g}\right.$ TPF $\mathrm{g}^{-1} \mathrm{~min}^{-2}$ for K20 and $1.31 \times 10^{-5} \mu \mathrm{g} \mathrm{TPF} \mathrm{g} \mathrm{gmin}^{-2}$ for K21). It was lower in summer $\left(9.95 \times 10^{-6} \mu \mathrm{g} \mathrm{TPF} \mathrm{g}^{-1} \mathrm{~min}^{-2}\right.$ for K20 and $7.28 \times 10^{-6} \mu \mathrm{g} \mathrm{TPF} \mathrm{g}{ }^{-1} \mathrm{~min}^{-2}$ for K21) and the lowest in spring $\left(5.1 \times 10^{-6} \mu \mathrm{g} \mathrm{TPF} \mathrm{g}{ }^{-1} \mathrm{~min}^{-2}\right.$ for K20 and $4.17 \times 10^{-6} \mu \mathrm{g} \mathrm{TPF} \mathrm{g}{ }^{-1} \mathrm{~min}^{-2}$ for K21). Only one studied soil raster (K21-152) displayed a different trend, although the highest DA was still detected in the monoculture soil in autumn. As a result of applying the Gorzow mixture in field K20, DA increased (Figure 3), indicating more favorable conditions for microbial growth and activity in the soil environment than in field K21. 


\subsection{Bacterial Biodiversity at the Phylum Level}

The main phyla of bacteria in the studied rasters of field K20 under the intercropping mixture and field K21 under the maize monoculture in the spring, summer, and autumn seasons are shown in Figure 4.
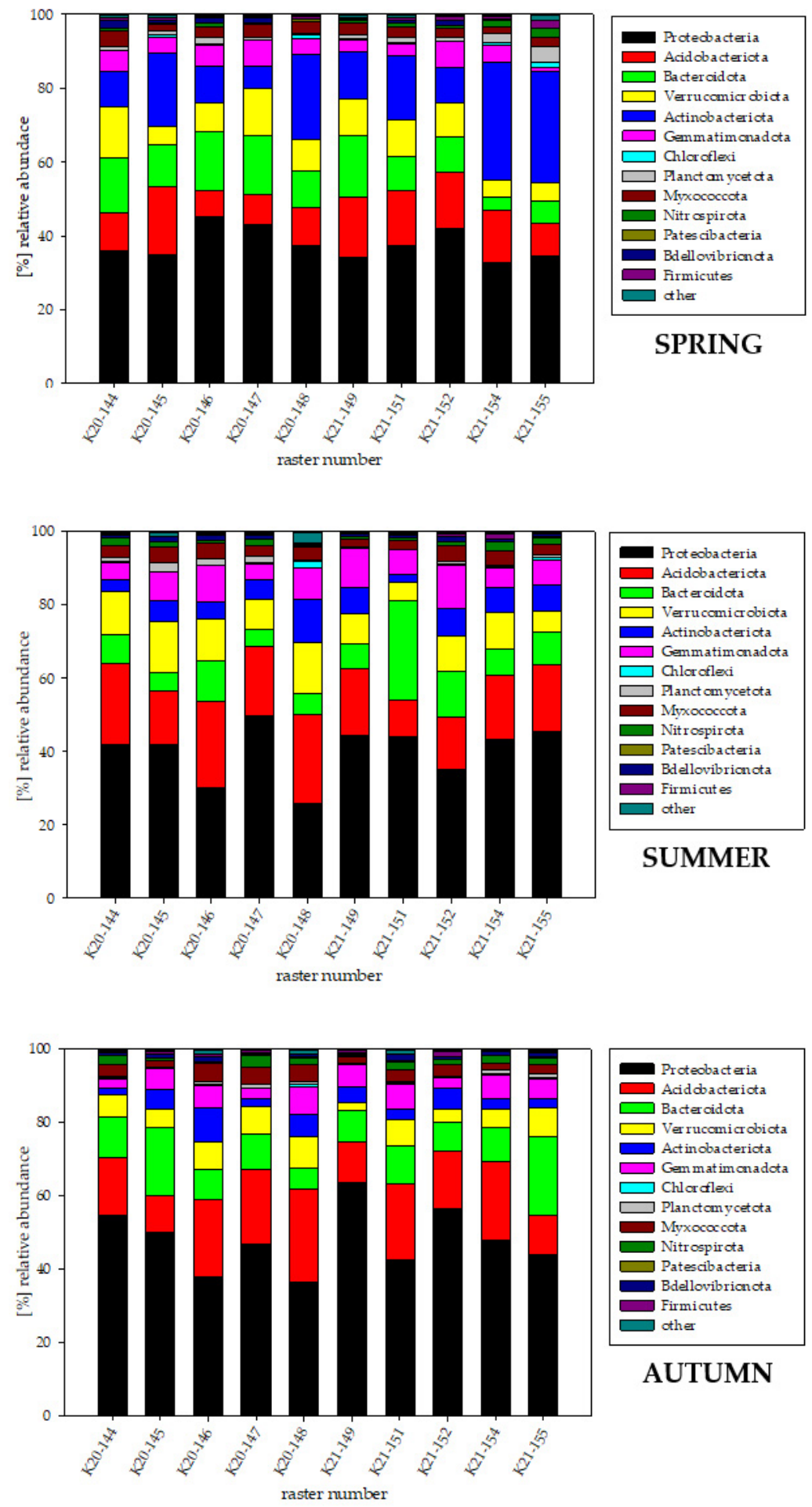

Figure 4. Bacterial phyla in the rasters of field K20 under the intercropping mixture and field K21 under the maize monoculture in spring, summer, and autumn.

Proteobacteria were the dominants (34.88-45.17\% for K20 and 32.82-41.83\% for K21 in spring; 36.45-54.51\% for K20 and 42.32-63.76\% for K21 in summer; $25.97-49.69 \%$ for K20 
and $35.05-45.67 \%$ for K21 in autumn) in each of the studied rasters. However, their abundance differed depending on the season and the mode of land cultivation (intercropping mixture or long-term maize monoculture). The amount of Proteobacteria in spring was relatively constant and comparable in both the K20 and K21 rasters, although a significant increase in their abundance was observed in all the K21 rasters in summer, where the long-term monoculture of maize was carried out, and especially in raster K21-149, where the amount of Proteobacteria was $63.76 \%$ (approx. 1.9-fold higher than in spring).

Field K20 in summer was still rich in Proteobacteria; however, their presence decreased in two (K20-146 and K20-148) of the five rasters (by 7.35\% and 1.01\%, respectively). Moreover, an increase in the Proteobacteria relative abundance was observed in autumn compared to spring and summer, though rasters K20-147, K21-151, and K21-155 showed relatively comparable Proteobacteria abundance in all seasons (spring, summer, and autumn).

Acidobacteriota appeared to be subdominant in summer $(9.69-25.17 \%$ for rasters K20-145 and K20-148, respectively; 10.74-21.59\% for rasters K21-155 and K21-154, respectively) and autumn (14.84-24.07\% for K20-145 and K20-148, respectively; $9.94-18.17 \%$ for K21-151 and K21-149, respectively). Interestingly, in spring, Actinobacteriota appeared to be the subdominant phylum occurring in much higher abundance than Acidobacteriota, especially in rasters K21-154 (31.89\%) and K21-155 (30.10\%). The analysis conducted in the same season revealed that the mean abundance of Actinobacteriota (13.72\%) in K20 slightly exceeded that of Bacteroidota (13.54\%), and Acidobacteriota (10.92\%) ranked fourth in abundance. In turn, the abundance of phyla in both fields in summer ranked as follows: Proteobacteria > Acidobacteriota > Bacteroidota; however, Gemmatimonadota (5.69\%) ranked fourth place in K21, thus slightly surpassing Verrucomicrobiota $(5.20 \%)$ and Actinobacteriota $(3.56 \%)$. In comparison, Verrucomicrobiota $(6.88 \%)>$ Actinobacteriota $(5.01 \%)$ $>$ Gemmatimonadota (4.90\%) dominated in field K20, in addition to the first three types common to both fields. The relative bacterial phylum biodiversity in autumn showed similarity between the dominants and sub-dominants in both fields (K20 and K21), and these were invariably Proteobacteria (37.91\% and $42.50 \%$ for K20 and K21, respectively) and Acidobacteriota (20.75\% and $15.53 \%$, respectively). The relative abundance of the phyla in the studied soils decreased in the case of these two dominants compared to summer and autumn for K20 and summer for K21. Besides the first two indicated phyla, Verrucomicrobiota $(11.83 \%)>$ Gemmatimonadota $(7.06 \%)>$ Bacteroidota $(6.77 \%)>$ Actinobacteriota $(6.23 \%)$ $>$ Myxococcota $(3.72 \%)>$ Planctomycetota $(1.49 \%)>$ Nitrospirota $(1.21 \%)$ dominated in K20, while Bacteroidota $(12.62 \%)>$ Gemmatimonadota $(8.26 \%)>$ Verrucomicrobiota $(7.67 \%)$ $>$ Actinobacteriota $(6.17 \%)>$ Myxococcota $(3.02 \%)>$ Nitrospirota $(1.36 \%)$ were dominant in K21. The relative abundance of Chloroflexi, Patescibacteria, Bdellovibrionota, and Firmicutes oscillated below $1 \%$ in each case. Sequences with an abundance of less than $0.1 \%$ were included in the "other" group (Figure 4).

\subsection{Bacterial Biodiversity at the Genus Level}

At the genus taxonomic level, the bacterial structure was highly differentiated depending on the raster studied, the agricultural practice applied, and the season (Figure 5).

The NGS analysis showed that the following dominant bacterial genera in field K20 in spring: Gaiella (11.88\% for K20-148 and 7.44\% for K20-145); Rhodanobacter (8.22\% for K20-148), RB41 (7.03\% for K20-144), Arenimonas (6.24\% for K20-147, 6.01\% for K20-146, and $5.65 \%$ for K20-144), Gemmatimonas (6.91\% for K20-147 and approx. $4.0 \%$ in rasters K20-145, K20-146, and K20-148), Mucilaginibacter (4.4\% for K20-148 and 5.62\% for K20-145), and Bryobacter (0.78\% for K20-146 and 5.68\% for K20-148).

In comparison, the monoculture field $\mathrm{K} 21$ was dominated by the following genera (Figure 5): Gaiella (3.75\% for K21-152 and 8.60\% for K21-155), Gemmatomonas (1.01\% for K21-155 and $6.86 \%$ for K21-152), RB41 (2.56\% for K21-151 and 5.42\% for K21-155), and Bryobacter (0.60\% for K21-155 and 5.99\% for K21-149). 


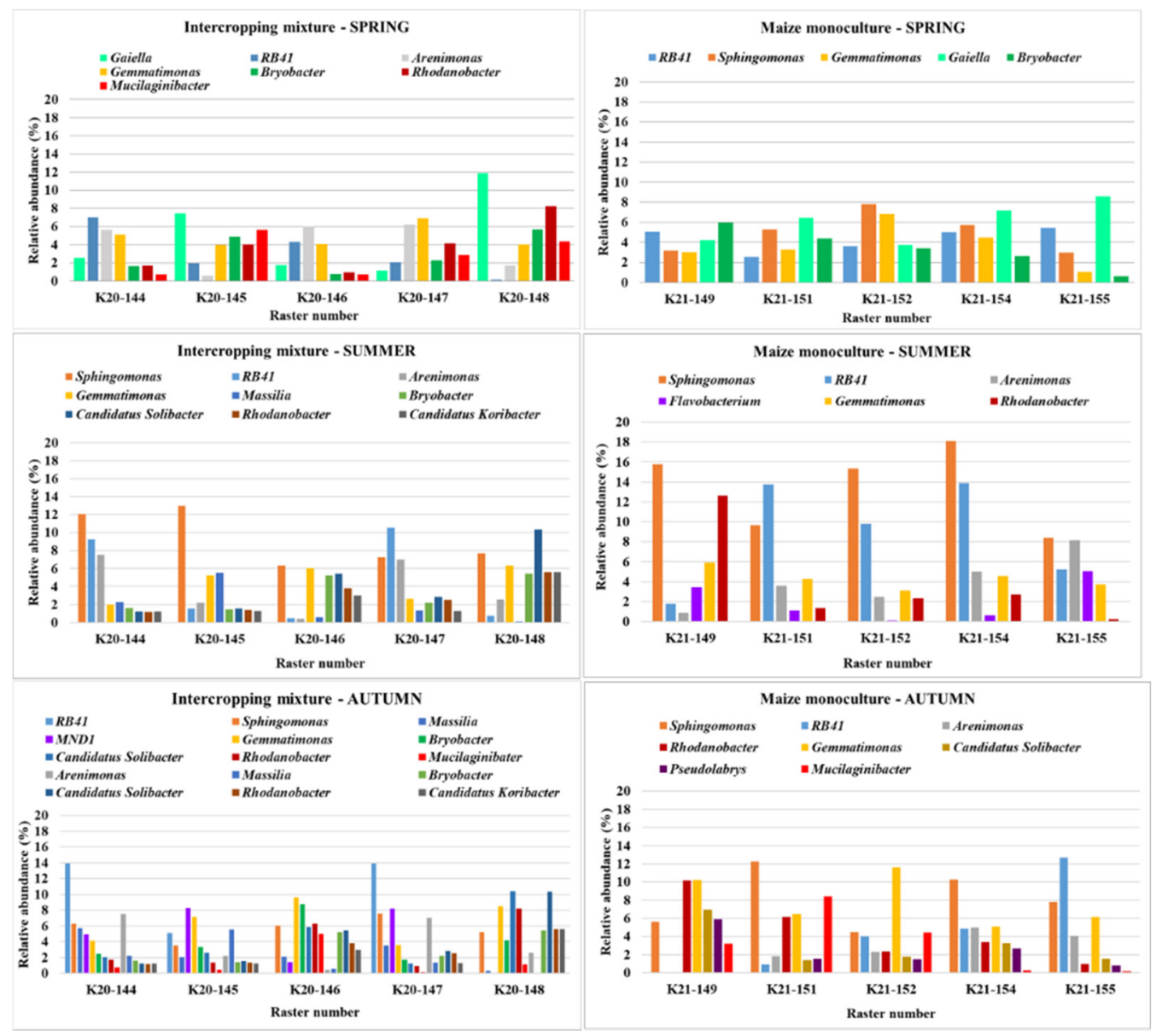

Figure 5. Dominant bacterial genera in the rasters of field K20 under the intercropping mixture and field K21 under the maize monoculture in spring, summer, and autumn.

In spring, the following genera of soil bacteria were present in field K20 as subdominant microbiota ( $>2 \%$ of the identified sequences): Sphingomonas $(2.74-4.62 \%)$, Massilia (2.59-4.53\%), Flavobacterium (0.32-3.89\%), Ellin6067 (0.93-2.86\%), Candidatus Udaeobacter $(0.32-2.83 \%)$, Candidatus Solibacter (0.28-4.68\%), Pseudolabrys (0.22-3.66\%), MND1 (0.66-4.37\%), Edaphobaculum (0.59-4.16\%), and Nocardioides (0.46-2.13\%). The same bacterial genera were found as subdominants in field K21 in spring; they occurred in a similar percentage range, suggesting that applying precision farming principles in long-term monocultures does not degrade indigenous bacterial biodiversity (Figure 5).

In summer, in the field sown with the Gorzow mixture (K20), the NGS analyses revealed the presence of 9 bacterial genera as dominants: Sphingomonas (6.35-12.99\%), RB41 (0.43-10.55\%), Arenimonas (2.56-7.54\%), Gemmatimonas (1.97-6.36\%), Massilia (0.55-5.54\%), Bryobacter (1.41-5.41\%), Candidatus Solibacter (1.21-10.34\%), Rhodanobacter (1.14-5.59), and Candidatus Koribacter (1.23-5.58\%). In comparison, field K21 was dominated by the following 6 genera: Sphingomonas (8.41-18.09\%), RB41 (1.81-13.90\%), Arenimonas $(0.88-8.17 \%)$, Flavobacterium (0.65-5.06\%), Gemmatimonas (3.12-5.93\%), and Rhodanobacter (0.24-12.63\%) (Figure 5).

In autumn, field K20 was dominated by 9 bacterial genera: RB41, Sphingomonas, Massilia, MND1, Gemmatimonas, Bryobacter, Candidatus Solibacter, Rhodanobacter, and Mucilaginibacter, while 8 genera were identified as dominants in field K21: Sphingomonas, RB41, Arenimonas, Rhodanobacter, Gemmatimonas, Candidatus Solibacter, Pseudolabrys, and Mucilaginibacter. The subdominants in the bacterial structure in fields K20 and K21 in autumn were represented by as many as 12 bacterial genera (Figure 5). 


\subsection{Bacterial Indicators of Sensitivity and Resistance to Maize Monoculture}

Our study allowed us to identify new bacterial indicators of the susceptibility to maize monoculture in spring, summer, and autumn (Figure 6). During the early growing season (spring), 14 bacterial genera showing sensitivity to the maize monoculture were detected, and the relative abundance of these bacteria was in the range of $0.58-4.81 \%$ for field K20 and $0.53-3.72 \%$ (Lysobacter-Gemmatimonas) for field K21. Fields K20 and K21 had an even higher abundance of bacteria showing sensitivity to the maize monoculture during summer. At that time, 16 bacterial genera were recorded, whose abundance based on Reyranella and Gemmatimonas was $1.02-4.44 \%$ for field K20 and 0.70-4.03\% for field K21, respectively. In the studied spectrum, the lowest biodiversity at the generic level was observed in autumn. The presence of 11 bacterial genera was then observed, with the highest abundance attributed to RB41 (6.59\% and $4.51 \%$ for K20 and K21, respectively) and the lowest abundance of Rhodanoplanes (1.09\%) for field K20 and Chthoniobacter $(0.53 \%)$ for field K21. Our results indicate that the bacterial abundance was significantly higher in field K20 with respect to field K21, where the long-term maize monoculture was used.

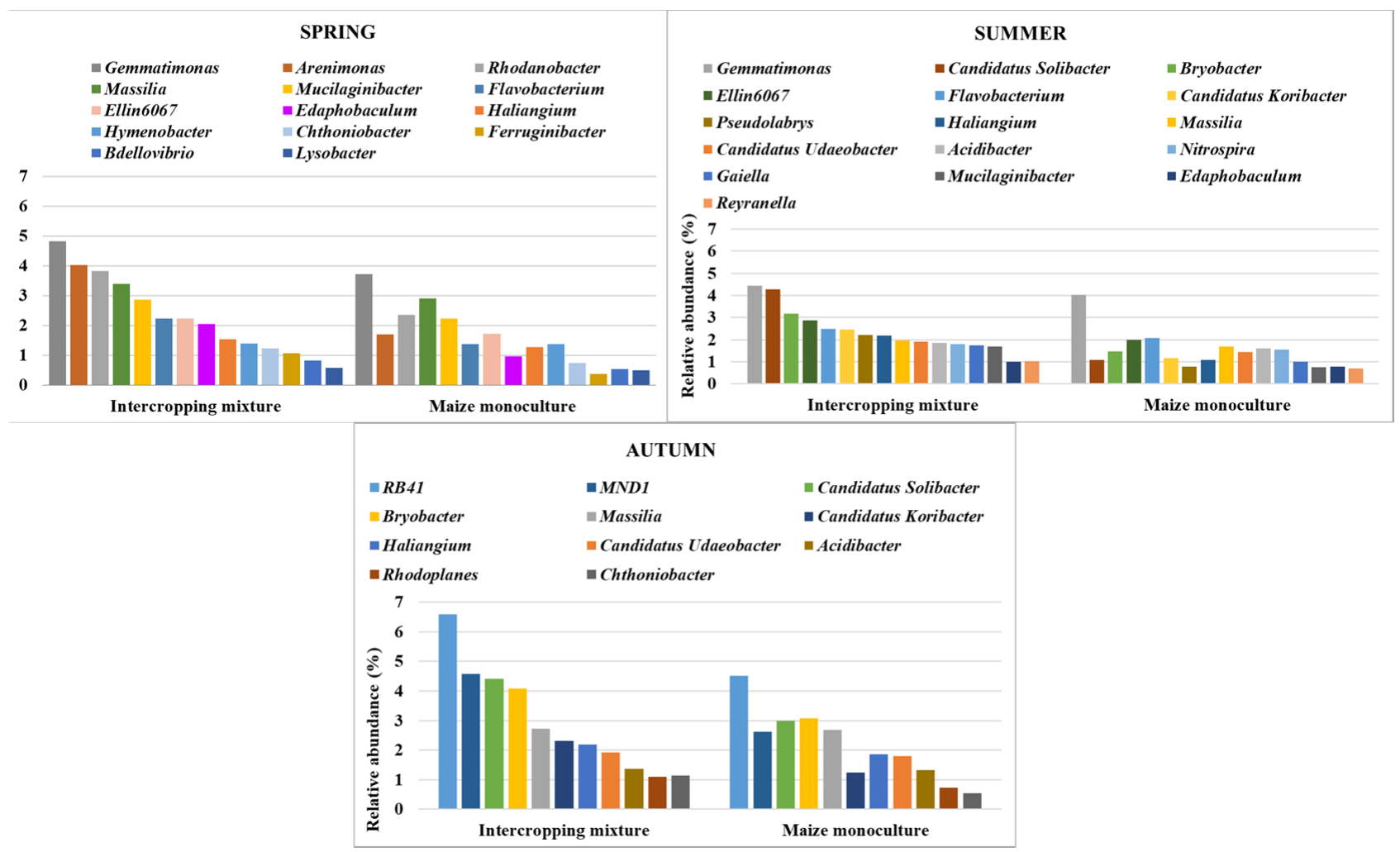

Figure 6. Bacterial genera with sensitivity to the maize monoculture in spring, summer, or autumn.

The analysis of the results discussed above distinguished two types of bacteria detected in each of the three studied growing seasons (spring, summer, autumn). These include Massilia (3.40\% for K20 and 2.90\% for K21 soils in spring, analogously $1.95 \%$ and $1.60 \%$ in summer, and $2.73 \%$ and $2.48 \%$ in autumn) and Haliangium (1.55\% and $1.26 \%$ for K20 and K21 soils in spring, analogously $2.17 \%$ and $1.07 \%$ in summer, and $2.19 \%$ and $1.86 \%$ in autumn, respectively).

Due to their repeatability in each season (a decrease in the abundance in the maize monoculture soil in respect to the intercropping mixture field), these genera of bacteria can be recommended as indicators of sensitivity to maize monoculture (Figure 7). 

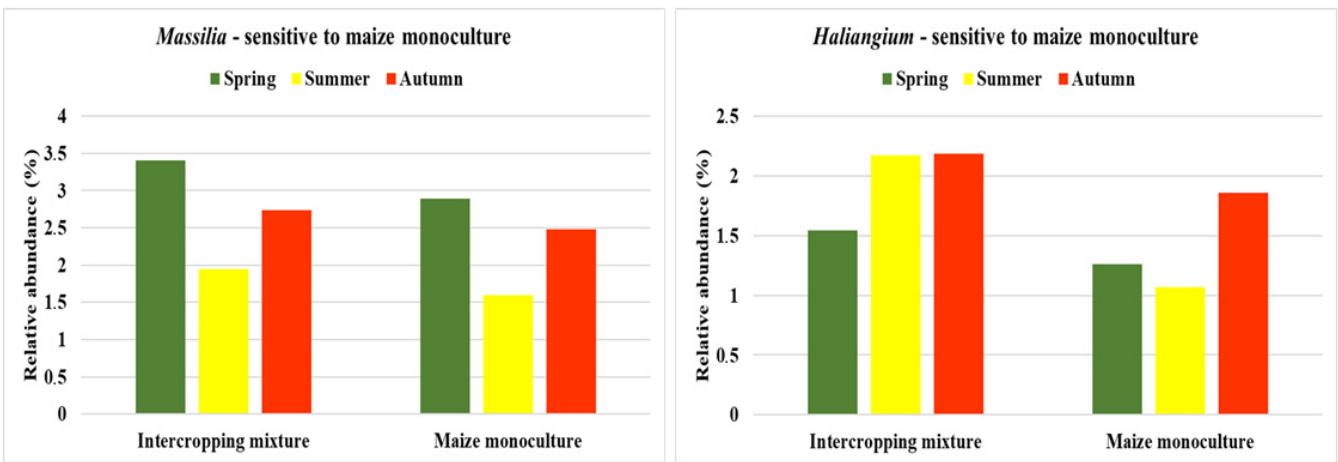

Figure 7. Bacterial genera recommended as sensitive to maize monoculture in all studied seasons.

We also analyzed the diversity of bacterial genera in the context of genera characterized by higher relative abundance in the field under the maize monoculture (K21) compared to K20-the intercropping mixture (Figure 8).

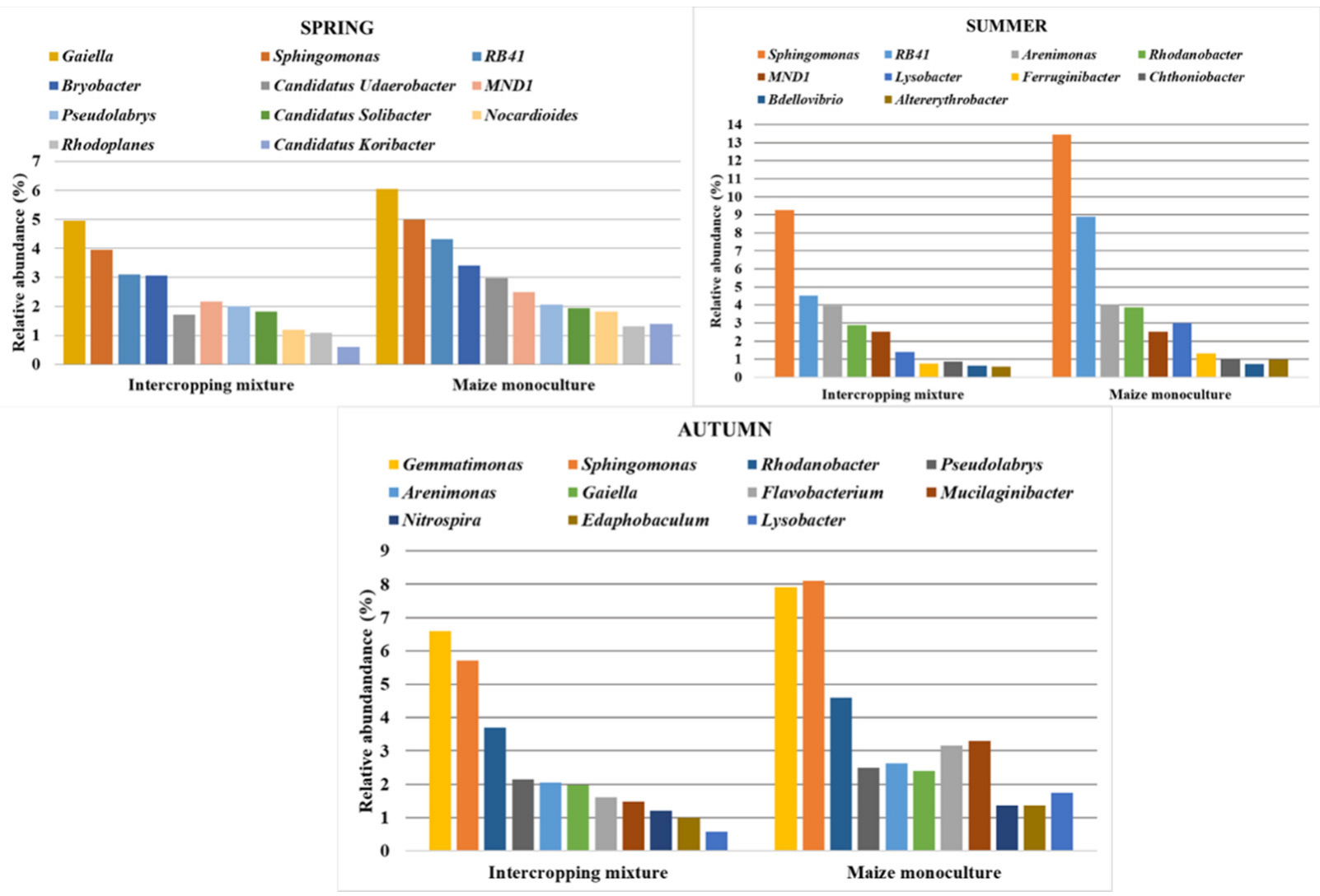

Figure 8. Bacterial genera with resistance to maize monoculture in spring, summer, or autumn.

Eleven genera of bacteria were characterized in the spring, with the following predominant genera: Gaiella (4.96\% and 6.04\% for K20 and K21), Sphingomonas (3.95\% and $4.99 \%)$, and RB41 (3.09\% and 4.33\%). The highest abundance was observed in summer when 10 bacterial genera were distinguished. The most representative bacterial genera in this respect were Sphingomonas (9.27\% and $13.45 \%$ for K20 and K21), RB41 (4.50\% and 8.90\% for K20 and K21), and Arenimonas (3.95\% and 4.03\%). In autumn, 11 bacterial genera were identified, with the dominance of Gemmatimonas (6.59\%) in the K20 field and Sphingomonas $(8.11 \%)$ in the K21 field. Interestingly, the genus RB41, which was highly abundant in the investigated soils in spring and summer, was not detected in autumn. 
The comparison of the results obtained during the three terms of the vegetation seasons revealed that one genus of bacteria, i.e., Sphingomonas, was classified as resistant to the maize monoculture, as it increased its abundance in field K21 versus K20 (Figure 9).

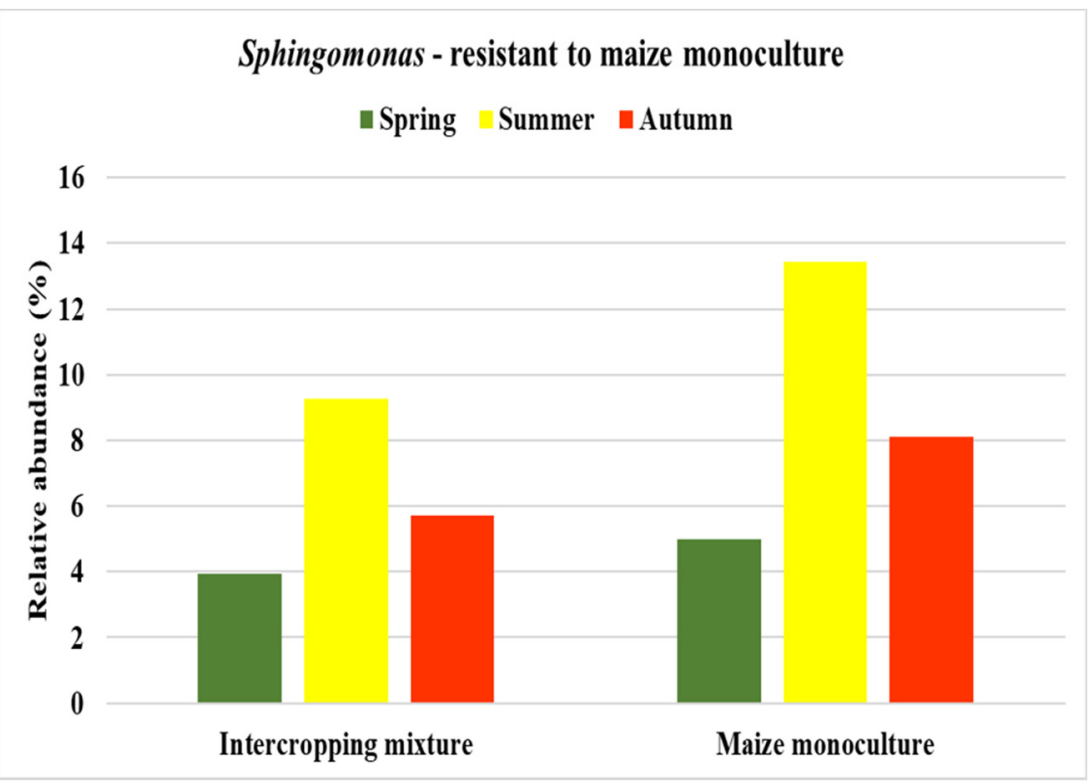

Figure 9. Bacterial genus recommended as resistant to maize monoculture in all studied seasons.

The relative abundance of Sphingomonas was 3.95\% and 4.99\% in K20 and K21, respectively, in spring, $9.27 \%$ and $13.45 \%$ in summer, and 5.71 and $8.11 \%$ in autumn. Therefore, it was concluded that the genus Sphingomonas could indicate resistance to maize monoculture (Figure 9).

\subsection{Biodiversity Indices and Beta-Diversity}

The abundance of common and different bacterial genera in the soil under the intercropping mixture and maize monoculture is presented in the form of a Venn diagram (Figure 10).

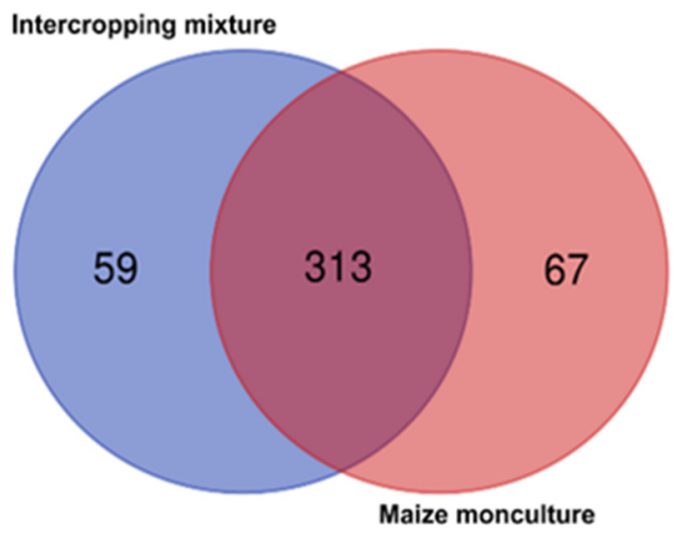

Figure 10. Venn diagram illustrating the numbers of common and different genera in soils under the intercropping mixture and maize monoculture.

It was noted that 313 genera of bacteria were common to both investigated fields (K20 and K21). In the field where the Gorzow mixture was applied (K20), 59 bacterial genera were detected, which, in turn, were not confirmed in the monoculture field (K21). In comparison, 67 genera that did not occur in field K20 were detected in K21. Overall, a more abundant microbiome at the genus taxonomic level was present in the monoculture 
soils, suggesting that applying precision agriculture principles to long-term monocultures does not degrade indigenous bacterial biodiversity.

The biodiversity indices obtained from the NGS analyses were illustrated using Shannon-Weaver and Simpson metrics (Figure 11). The Shannon diversity index $\left(H^{\prime}\right)$ reached values above 4.00 in both fields (K20 and K21) in each season. In spring, it ranged from 4.45 to 4.48 in the field where the Gorzow mixture was applied (K20) and in the monoculture field (K21), respectively.
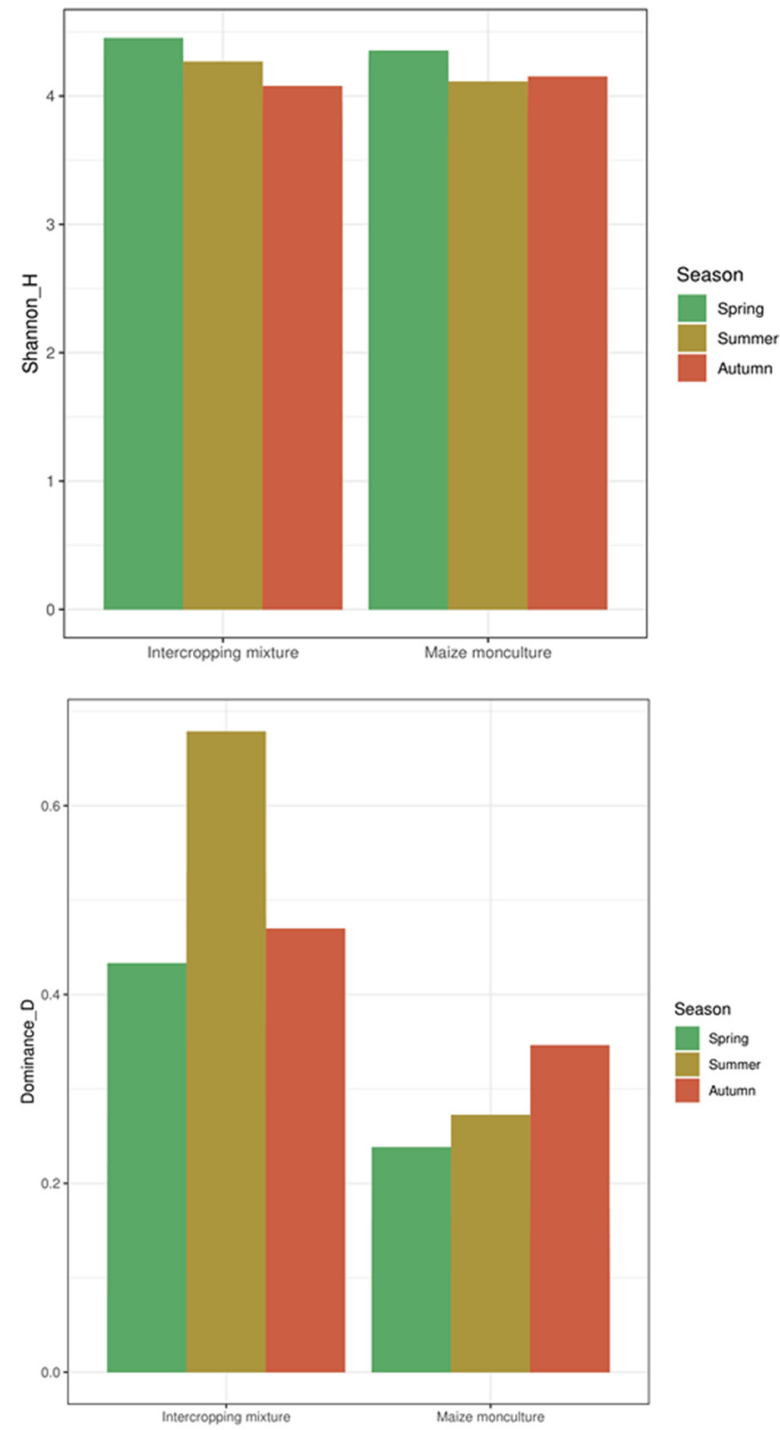

Figure 11. Shannon-Weaver biodiversity index and Simpson dominance index values in the different terms of the vegetation season in the fields under the intercropping mixture and maize monoculture.

In summer, $H^{\prime}$ decreased and ranged from 4.24 in field K20 and 4.11 in field K21. Interestingly, the Shannon index in autumn reached a higher value (4.15) in field K21 than in K20 (4.06) (Figure 10).

The changeability of the Simpson dominance index $(D)$ is presented in Figure 11. In soils where the intercrop mixture (K20) was applied, it remained relatively constant in spring and summer (approx. 0.04) but was over 0.05 in autumn. In the long-term monoculture field (K21), $D$ reached the lowest value in spring (over 0.024), a higher level in autumn (over 0.051), and the highest value in summer (over 0.063). 


\section{Discussion}

The use of the intercropping system can increase the yield potential [39] and improve soil quality by reducing artificial chemical pollution [40], inhibiting soil diseases [41], enhancing plant root function [42], increasing soil nutrient efficiency and spatial utilization [43], and promoting the biofunctionality of soil microorganisms [44]. Many reports show that agricultural practice and agrotechnical treatments have a great influence on the modification of soil chemical parameters [40,45-47]. The finding that soil chemical properties create specific niche conditions for microorganisms and thus indirectly affect the biological activity and microbial diversity in the soil environment was reported by Uzarowicz et al. [48] and Grzadziel et al. [49]. Our studies have shown that the application of different cultivation systems induced differences, e.g., in the chemical parameters of soils $(\mathrm{pH}, \mathrm{Eh}, \mathrm{TOC}$, moisture), depending on the term of the growing season. It was also confirmed that the indices of biological activity, such as enzymatic and respiratory activities, differ depending on the soil properties and the season.

Soil $\mathrm{pH}$ is one of the most easily measurable parameters defining soil quality [47-49]. It is referred to as the "major soil variable" influencing myriads of biological, chemical, and physical soil properties and processes involved in plant growth and biomass yield [50,51]. Importantly, adequate soil $\mathrm{pH}$ is essential for the proper enzymatic activity in soil $[52,53]$ and can indirectly regulate enzymes by influencing the microbiome producing these enzymes [54]. Our results showed a relationship between $\mathrm{pH}$ and the different seasons. It turned out that, in spring, the soil $\mathrm{pH}$ value was the closest to neutral in both the intercropping system (6.07-7.90 for field K20) and the long-term monoculture (5.82-7.93 for field K21). The investigated soils had the lowest acidity in summer and a slightly higher value in autumn in both fields $\mathrm{K} 20$ and $\mathrm{K} 21$. The Eh and pH of the environment largely determine the types of metabolism occurring in the soil bacterial community and are therefore important parameters of biological activity [55]. All the studied soils had an Eh value above $400 \mathrm{mV}$, which indicates that they are well aerated [56]. There was a clear increase in TOC, RA, and DA after applying the Gorzow mixture (K20), compared to the results obtained in the field with the long-term maize monoculture (K21). The highest mean values for RA (33.73 mg CO $\mathrm{kg}^{-1} \mathrm{~d}^{-1}$ for $\mathrm{K} 20$ and $28.16 \mathrm{mg} \mathrm{CO}_{2} \mathrm{~kg}^{-1} \mathrm{~d}^{-1}$ for K21), DA $\left(2.36 \times 10^{-5} \mu \mathrm{g}\right.$ TPF g ${ }^{-1} \mathrm{~min}^{-2}$ for K20 and $1.31 \times 10^{-5} \mu \mathrm{g} \mathrm{TPF} \mathrm{g}{ }^{-1} \mathrm{~min}^{-2}$ for K21), and TOC (an increase by $0.47 \%$ compared to field K21) were recorded in autumn. These results suggest that the increase in the values of the above-mentioned parameters is reflected in the improvement of the soil environment conditions promoting the development of microorganisms and indicates a beneficial effect of the intercropping system on soil quality.

As evidenced by Błońska [57], dehydrogenases are $\mathrm{pH}$-dependent, and their activity tends to increase with soil $\mathrm{pH}$, while Brzezińska et al. [58] and Włodarczyk [59] reported that the best $\mathrm{pH}$ conditions for DA oscillated in the range from 6.6 to 7.2. However, our study shows a definite DA increase after applying the Gorzow mixture, compared to the long-term maize monoculture. Moreover, in autumn, a higher DA value $\left(3.73 \times 10^{-5} \mu \mathrm{g}\right.$ TPF g $\left.{ }^{-1} \mathrm{~min}^{-2}\right)$ was recorded in raster $\mathrm{K} 20-145$ at $\mathrm{pH}=6.6$ than in raster $\mathrm{K} 20-146\left(\mathrm{DA}=1.82 \times 10^{-5} \mu \mathrm{g}\right.$ TPF g ${ }^{-1} \mathrm{~min}^{-2}$ ), where $\mathrm{pH}=6.95$, which indicates that DA does not always increase with increasing $\mathrm{pH}$, as claimed by Błońska [57]. A similar situation was observed in the case of raster K20-144, with DA $=2.25 \times 10^{-5} \mu \mathrm{g} \mathrm{TPF} \mathrm{g}{ }^{-1} \mathrm{~min}^{-2}$ and $\mathrm{pH}$ was 6.17, where a lower DA value was recorded in raster K20-147 despite the higher $\mathrm{pH}$ equal to 6.61. Additionally, the lowest $\mathrm{pH}$ recorded (5.99) in raster K20-148 among all the K20 field rasters examined in autumn was not accompanied by the lowest DA (DA $=1.95 \times 10^{-5} \mu \mathrm{g}$ TPF $\mathrm{g}^{-1} \mathrm{~min}^{-2}$ ), as in the case of raster K20-146 with $\mathrm{pH}=6.94$ $\left(\mathrm{DA}=1.82 \times 10^{-5} \mu \mathrm{g}\right.$ TPF $\left.\mathrm{g}^{-1} \mathrm{~min}^{-2}\right)$. This is at odds with the thesis of the aforementioned researchers, showing that DA does not always increase with increasing $\mathrm{pH}$ and that the highest DA values are not always reached at $\mathrm{pH}=6.6-7.2$, as demonstrated in the present study. A comparison was also made with field K21 (long-term maize monoculture), where significantly lower DA values were observed, although the trend was similar to that in field K20 (intercropping system). Thus, in raster K21-149, a DA 
value of $1.73 \times 10^{-5} \mu \mathrm{g}$ TPF $\mathrm{g}^{-1} \mathrm{~min}^{-2}$ was recorded at $\mathrm{pH}=5.99$, while the DA value at $\mathrm{pH}=6.99$ in raster $\mathrm{K} 21-155$ was $8.20 \times 10^{-6} \mu \mathrm{g} \mathrm{TPF} \mathrm{g}^{-1} \mathrm{~min}^{-2}$, i.e., the DA value was much lower than in raster K21-149, which again contradicts the thesis presented by Błońska [57], Brzezińska et al. [58], and Włodarczyk [59].

The present work also provides a comprehensive insight into the bacterial biodiversity structure at two taxonomic levels (phylum and genus). It was found that Proteobacteria and Acidobacteriota were the dominant phyla in the soil microbiome in the soils sampled from both fields K20 and K21. Nevertheless, the relative abundance of these bacteria varied with the season and the cropping system, which is consistent with previous studies [60-62]. It turned out that a marked increase in the Proteobacteria abundance was recorded in summer, both in K20 and K21, although surprisingly, the highest abundance was also recorded in the rasters of field $\mathrm{K} 21$, where the long-term maize monoculture was carried out. This may indicate that these bacteria can adapt to less favorable environmental conditions, which proves the validity of the study conducted by Wolinska et al. [63]. Acidobacteriota were the subdominant bacterial phylum in terms of the relative abundance noted in summer and autumn in fields K20 and K21. Interestingly, in spring, there was an increase in Actinobacteriota abundance in the rasters of field K20 and an even greater increase in the rasters of field $\mathrm{K} 21$, thus showing their subdominance at this time of year. It is known that Acidobacteriota are commonly found in soils with acidic $\mathrm{pH}$ [64]; moreover, lower $\mathrm{pH}$ levels support their higher abundance $[65,66]$, which is related to the lowest $\mathrm{pH}$ values obtained only in spring (Table 1). An ecologically important group of bacteria in soils are representatives of the Bacteroidota phylum, which were also considerably abundant in the studied rasters. There are studies confirming that Bacteroidota can be considered as indicators of, e.g., fatigue of agricultural soils $[67,68]$.

Our results show a definite increase in the richness of bacterial biodiversity at the genus level in the rasters of the field treated with the intercropping system (K20) compared to the field treated with the maize monoculture (K21) (Figure 5). A similar trend was shown by Xiao et al. [69], who proved that intercropping with green garlic significantly increased the population of bacteria and actinomycetes in cucumber/garlic intercrops [69]. Furthermore, it was proved that onion or garlic intercropping with cucumber promoted both bacterial and fungal communities, and the effects persisted over subsequent growing seasons [70]. Overall, various studies confirm the positive effects of intercropping, i.e., increased soil microbial diversity, for example, the intercropping system in wheatsoybean [71], maize/wheat-fava bean [72], millet-mung bean [73], and maize-peanut [74]. It is argued that the level of soil bacterial diversity plays an important role in maintaining the stability of the agricultural ecosystem, improving crop resistance, crop growth, yield formation, and plant diversity. It also ensures the diversity of soil bacterial communities and reduces the abundance of pathogenic microorganisms [75]. Similarly, in the present study, one genus was selected as a pathogen, namely Bdellovibrio; however, it was present in low numbers, and no negative effect of these bacteria on the studied soils was observed.

The NGS analysis allowed us to select indicators of sensitivity and resistance to long-term maize monoculture, which is undoubtedly a novelty in the presented results. Two types of bacteria: Massilia and Haliangium, were recognized and recommended as indicators of sensitivity to maize monoculture, which was evidenced by the decrease in their abundance in the soil with the maize monoculture (K21), compared with the field with the intercrop mixture (K20) (Figure 7). One genus, Sphingomonas, was also identified as resistant to maize monoculture, as evidenced by the increase in the abundance of this bacterium in field K21 compared to field K20. Sphingomonas was abundant in our rasters, especially in the samples of field K20, and dominated there especially in summer, autumn, and spring, but it should be noted that it is one of the endophytic bacteria of maize [76].

\section{Conclusions}

Our results demonstrate that the application of the intercropping system has a beneficial effect on the chemical properties and enzymatic activity. It contributes to improving 
soil quality and an increase in the richness and diversity of soil bacteria at the taxonomic level of genera compared to maize monoculture, as shown by the results from the three terms of the growing season. However, it should be noted that the level of biodiversity in the field where the long-term maize monoculture was grown was also satisfactory.

We have shown that biodiversity and bacterial abundance were correlated with the season and cropping system used, with a noticeable increase in the biodiversity and abundance of the bacterial microbiome at the genus level in the rasters of field K20. Using the NGS analysis, we were able to identify bacteria that act as indicators of sensitivity and resistance to long-term maize monoculture. Thus, Massilia and Haliangium were selected as indicators of sensitivity to maize monoculture, as evidenced by the decrease in their abundance in the maize monoculture soil (K21) compared to the field with the intercropping mixture (K20). We have proved that Sphingomonas is an indicator of resistance to maize monoculture due to the increase in the abundance of this bacterium in field K21 compared to field K20.

Considering the research hypotheses, we have proved that intercropping improves soil biological quality compared to long-term monocultures. Nevertheless, further studies are needed (i.e., lasting longer than one vegetation season) to elucidate its effect on soil bacterial community structure and diversity.

Author Contributions: Conceptualization, A.W. and A.K. (Anna Kruczyńska); methodology, A.K (Agnieszka Kuźniar), A.S., J.G. and A.G.; software, J.G. and A.S.; validation, A.W., J.P., A.K. (Anna Kruczyńska), A.K. (Agnieszka Kuźniar) and J.G.; formal analysis, A.W., A.K. (Anna Kruczyńska), A.K. (Agnieszka Kuźniar) and J.G.; investigation, A.S., A.K. (Anna Kruczyńska) and A.K. (Agnieszka Kuźniar); writing - original draft preparation, A.K. (Anna Kruczyńska) and A.W.; writing-review and editing, A.K. (Agnieszka Kuźniar), J.P., A.S, A.G. and J.G.; visualization, A.W. and A.K. (Agnieszka Kuźniar); funding acquisition, J.P. and A.S. All authors have read and agreed to the published version of the manuscript.

Funding: This research was funded by the Potulicka Foundation Economic Center, grant number UKDKW 1 March 2020.

Institutional Review Board Statement: Not applicable.

Informed Consent Statement: Not applicable.

Data Availability Statement: The data presented in this study are available on request from the corresponding author.

Acknowledgments: The study was supported by the Potulicka Foundation Economic Center (in the frame of UKDKW 1 March 2020). The authors thank technical staff Anna Sochaczewska and Andrzej Górski for their help in laboratory experiments and Anna Szafranek-Nakonieczna for her help in respiration calculation.

Conflicts of Interest: The authors declare no conflict of interest.

\section{References}

1. Yang, X.; Wang, Y.; Sun, L.; Qi, X.; Song, F.; Zhu, X. Impact of maize-mushroom intercropping on the soil bacterial community composition in Northeast China. Agronomy 2020, 10, 1526. [CrossRef]

2. Zhu, X.C.; Sun, L.Y.; Song, F.B.; Liu, S.Q.; Liu, F.L.; Li, X.N. Soil microbial community and activity are affected by integrated agricultural practices in China. Eur. J. Soil Sci. 2018, 69, 924-935. [CrossRef]

3. Ullah, S.; Ai, C.; Huang, S.; Song, D.; Abbas, T.; Zhang, J.; Zhou, W.; He, P. Substituting ecological intensification of agriculture for conventional agricultural practices increased yield and decreased nitrogen losses in North China. Appl. Soil Ecol. 2020, 147, 103395. [CrossRef]

4. Uchida, S.; Hayashi, K. Comparative life cycle assessment of improved and conventional cultivation practices for energy crops in Japan. Biomass Bioenergy 2012, 36, 302-315. [CrossRef]

5. Heinze, S.; Vogel, A. Reversion from organic to conventional agriculture in Germany. Build. Org. Brid. 2014, $20,347-350$.

6. Stroud, J.L. Soil health pilot study in England: Outcomes from an on-farm earthworm survey. PLoS ONE 2019, 14, e0203909. [CrossRef]

7. Domagała-Świątkiewicz, I.; Gąstoł, M. Soil chemical properties under organic and conventional crop management systems in south Poland. Biol. Agric. Hortic. 2013, 29, 12-28. [CrossRef] 
8. Munkholm, L.J.; Heck, R.J.; Deen, B. Long-term rotation and tillage effects on soil structure and crop yield. Soil Tillage Res. 2013, 127, 85-91. [CrossRef]

9. Doula, M.K.; Sarris, A. Chapter 4-Soil environment. In Environment and Development; Poulopoulos, S.G., Inglezakis, V.J., Eds.; Elsevier: Amsterdam, The Netherland, 2016; pp. 213-286.

10. Zhang, B.; Li, Y.; Ren, T.; Tian, Z.; Wang, G.; He, X.; Tian, C. Short-term effect of tillage and crop rotation on microbial community structure and enzyme activities of a clay loam soil. Biol. Fertil. Soils 2014, 50, 1077-1085. [CrossRef]

11. Chen, H.; Hou, R.; Gong, Y.; Li, H.; Fan, M.; Kuzyakov, Y. Effects of 11 years of conservation tillage on soil organic matter fractions in wheat monoculture in Loess Plateau of China. Soil Tillage Res. 2009, 106, 85-94. [CrossRef]

12. Griffiths, B.S.; Philippot, L. Insights into the resistance and resilience of the soil microbial community. FEMS Microbiol. Rev. 2013, 37, 112-129. [CrossRef] [PubMed]

13. Coudrain, V.; Hedde, M.; Chauvat, M.; Maron, P.; Bourgeois, E.; Mary, B.; Léonard, J.; Ekelund, F.; Villenave, C.; Recous, S Temporal differentiation of soil communities in response to arable crop managenment strategies. Agric. Ecosyst. Environ. 2016, 225, 12-21. [CrossRef]

14. Li, L.; Zhang, L.; Zhang, F. Crop mixtures and the mechanisms of overyielding. Encycl. Biodivers. 2013, 2, $382-395$.

15. Askari, M.S.; Holden, N.M. Indices for quantitative evaluation of soil quality under grassland management. Geoderma 2014, 230-231, 131-142. [CrossRef]

16. Wolińska, A.; Rekosz-Burlaga, H.; Goryluk-Salmonowicz, A.; Błaszczyk, M.K.; Stępniewska, Z. Bacterial Abundance and Dehydrogenase Activity in Selected Agricultural Soils from Lublin Region. Pol. J. Environ. Stud. 2015, 24, 2677-2682. [CrossRef]

17. Brooker, R.W.; Bennett, A.E.; Cong, W.F.; Daniell, T.J.; George, T.S.; Hallett, P.D.; Hawes, C.; Iannetta, P.P.M.; Jones, H.G.; Karley, A.J.; et al. Improving intercropping: A synthesis of research in agronomy, plant physiology and ecology. New Phytol. 2015, 206, 107-117. [CrossRef]

18. Zhao, Q.; Xiong, W.; Xing, Y.; Sun, Y.; Lin, X.; Dong, Y. Long-Term Coffee Monoculture Alters Soil Chemical Properties and Microbial Communities. Sci. Rep. 2018, 8, 6116. [CrossRef]

19. Stomph, T.; Dordas, C.; Baranger, A.; Bedoussac, L.; de Rijk, J.; Dong, B.; Evers, J.; Gu, C.; Li, L.; Simon, J.; et al. Designing intercrops for high yield, yield stability and efficient use of resources: Are there principles? In Advances in Agronomy; Academic Press: Cambridge, MA, USA, 2020; Volume 160, pp. 1-50.

20. Zhu, J.; van der Werf, W.; Anten, N.P.R.; Vos, J.; Evers, J.B. The contribution of phenotypic plasticity to complementary light capture in plant mixtures. New Phytol. 2015, 207, 1213-1222. [CrossRef]

21. Zaeem, M.; Nadeem, M.; Pham, T.H.; Ashiq, W.; Ali, W.; Gilani, S.S.M.; Elavarthi, S.; Kavanagh, V.; Cheema, M.; Galagedara, L.; et al. The potential of corn-soybean intercropping to improve the soil health status and biomass production in cool climate boreal ecosystems. Sci. Rep. 2019, 9, 13148. [CrossRef]

22. Du, Q.; Zhou, L.; Chen, P.; Liu, X.; Song, C.; Yang, F.; Wang, X.; Liu, W.; Sun, X.; Du, J.; et al. Relay-intercropping soybean with maize maintains soil fertility and increases nitrogen recovery efficiency by reducing nitrogen input. Crop J. 2020, 8, 140-152 [CrossRef]

23. Bedoussac, L.; Journet, E.P.; Hauggaard-Nielsen, H.; Naudin, C.; Corre-Hellou, G.; Jensen, E.S.; Prieur, L.; Justes, E. Ecological principles under lying the increase of productivity achieved by cereal-Grain legume intercrops in organic farming. A review. Agron. Sustain. Dev. 2015, 35, 911-935. [CrossRef]

24. Lithourgidis, A.; Dordas, C.; Damalas, C.; Vlachostergios, D. Annual Intercrops: An Alternative Pathway for Sustainable Agriculture. Aust. J. Crop Sci. 2011, 5, 396-410.

25. Pankou, C.; Lithourgidis, A.; Dordas, C. Effect of Irrigation on Intercropping Systems of Wheat (Triticum aestivum L.) with Pea (Pisum sativum L.). Agronomy 2021, 11, 283. [CrossRef]

26. Raza, A.; Razzaq, A.; Mehmood, S.S.; Zou, X.; Zhang, X.; Lv, Y.; Xu, J. Impact of Climate Change on Crops Adaptation and Strategies to Tackle Its Outcome: A Review. Plants 2019, 8, 34. [CrossRef]

27. Bedoussac, L.; Journet, E.-P.; Hauggaard-Nielsen, H.; Naudin, C.; Corre-Hellou, G.; Jensen, E.S.; Justes, E. Grainlegumecerealinter cropping systems. In Achieving Sustainable Cultivation of Grain Legumes Volume 1: Advances in Breeding and Cultivation Techniques; Sivasankar, S., Ed.; Burleigh Dodds Science Publishing: Cambridge, UK, 2018.

28. Tang, X.; Zhang, C.; Yu, Y.; Shen, J.; van der Werf, W.; Zhang, F. Intercropping legumes and cereals increases phosphorus use efficiency; a meta-analysis. Plant Soil 2021, 460, 89-104. [CrossRef]

29. Xu, Y.; Feng, J.; Li, H. How intercropping and mixed systems reduce cadmium concentration in rice grains and improve grain yields. J. Hazard. Mater. 2021, 402, 123762. [CrossRef]

30. Schulz, V.S.; Schumann, C.; Weisenburger, S.; Müller-Lindenlauf, M.; Stolzenburg, K.; Möller, K. Row Intercropping Maize (Zea mays L.) with Biodiversity Enhancing Flowering-Partners-Effect on Plant Growth, Silage Yield, and Composition of Harvest Material. Agriculture 2020, 10, 524. [CrossRef]

31. Szafranek-Nakonieczna, A.; Stępniewska, Z. Aerobic and anaerobic respiration in profiles of Polesie Lubelskie peatlands. Int. Agrophysics 2014, 28, 219-229. [CrossRef]

32. Casida, L.E.; Klein, D.A.; Santoro, T. Soil dehydrogenase activity. Soil Sci. 1964, 98, 371-376. [CrossRef]

33. Wolińska, A.; Kuźniar, A.; Gałązka, A. Biodiversity in the rhizosphere of selected winter wheat (Triticum aestivum L.) cultivarsGenetic and catabolic fingerprinting. Agronomy 2020, 10, 953. [CrossRef] 
34. Thijs, S.; Op De Beeck, M.; Beckers, B.; Truyens, S.; Stevens, V.; Van Hamme, J.D.; Weyens, N.; Vangronsveld, J. Comparative evaluation of four bacteria-specific primer pairs for 16S rRNA gene surveys. Front. Microbiol. 2017, 8, 494. [CrossRef] [PubMed]

35. Wolińska, A.; Kuźniar, A.; Zielenkiewicz, U.; Banach, A.; Izak, D.; Stępniewska, Z.; Błaszczyk, M. Metagenomic analysis of some potential nitrogen-fixing bacteria in arable soils at different formation processes. Microb. Ecol. 2017, 73, 162-176. [CrossRef] [PubMed]

36. Kuźniar, A.; Włodarczyk, K.; Grządziel, J.; Goraj, W.; Gałązka, A.; Wolińska, A. Culture-independent analysis of an endophytic core microbiome in two species of wheat: Triticum aestivum L. (cv. 'Hondia') and the first report of microbiota in Triticum spelta L. (cv. 'Rokosz'). Syst. Appl. Microbiol. 2020, 43, 126025. [CrossRef] [PubMed]

37. Callahan, B.J.; McMurdie, P.J.; Rosen, M.J.; Han, A.W.; Johnson, A.J.A.; Holmes, S.P. DADA2: High-resolution sample inference from Illumina amplicon data. Nat. Methods 2016, 13, 581-583. [CrossRef]

38. Wright, E.S. Using DECIPHER v2.0 to Analyze Biological Sequence Data in R. R J. 2016, 8, 352-359. [CrossRef]

39. DeSantis, T.Z.; Hugenholtz, P.; Larsen, N.; Rojas, M.; Brodie, E.L.; Keller, K.; Dalevi, D.; Hu, P.; Andersen, G.L. Greengenes, a chimera-checked 16S rRNA gene database and workbench compatible with ARB. Appl. Environ. Microbiol. 2006, 72, 5069-5072. [CrossRef]

40. Reeve, J.R.; Hoagland, L.A.; Villalba, J.J.; Carr, P.M.; Atucha, A.; Cambardella, C.; Davis, D.R.; Delate, K. Chapter Six-Organic Farming, Soil Health, and Food Quality: Considering Possible Links. In Advances in Agronomy; Academic Press: Cambridge, MA, USA, 2016; Volume 137, pp. 319-367.

41. Lemaire, G.; Franzluebbers, A.; Carvalho, P.C.D.F.; Dedieu, B. Integrated crop-livestock systems: Strategies to achieve synergy between agricultural production and environmental quality. Agric. Ecosyst. Environ. 2014, 190, 4-8. [CrossRef]

42. Vukicevich, E.; Lowery, T.; Bowen, P.; Úrbez-Torres, J.R.; Hart, M. Cover crops to increase soil microbial diversity and mitigate decline in perennial agriculture. A review. Agron. Sustain. Dev. 2016, 36, 48. [CrossRef]

43. Bukovsky-Reyes, S.; Isaac, M.E.; Blesh, J. Effects of intercropping and soil properties on root functional traits of cover crops. Agric. Ecosyst. Environ. 2019, 285, 106614. [CrossRef]

44. Hinsinger, P.; Betencourt, E.; Bernard, L.; Brauman, A.; Plassard, C.; Shen, J.; Tang, X.; Zhang, F. P for two, sharing a scarce resource: Soil phosphorus acquisition in the rhizosphere of intercropped species. Plant Physiol. 2011, 156, 1078-1086. [CrossRef]

45. Sun, F.; Pan, K.; Olatunji, O.A.; Li, Z.; Chen, W.; Zhang, A.; Song, D.; Sun, X.; Huang, D.; Tan, X. Specific legumes allay drought effects on soil microbial food web activities of the focal species in agroecosystem. Plant Soil 2019, 437, 455-471. [CrossRef]

46. Lopes, A.R.; Faria, C.; Prieto-Fernandez, A.; Trasar-Cepeda, C.; Manaia, C.M.; Nunes, O.C. Comparative study of the microbial diversity of bulk paddy soil of two rice fields subjected to organic and conventional farming. Soil Biol. Biochem. 2011, 43, 115-125. [CrossRef]

47. Wolińska, A.; Szafranek-Nakonieczna, A.; Banach, A.; Rekosz-Burlaga, H.; Goryluk-Salmonowicz, A.; Błaszczyk, M.; Stępniewska, Z.; Górski, A. Biological degradation of arable soils from Lublin region (SE Poland). Int. J. Curr. Microbiol. Appl. Sci. 2014, 3, 558-571.

48. Uzarowicz, Ł.; Wolińska, A.; Błońska, E.; Szafranek-Nakonieczna, A.; Kuźniar, A.; Słodczyk, Z.; Kwasowski, W. Technogenic soils (Technosols) developed from mine spoils containing Fe sulphides: Microbiological activity as an indicator of soil development following land reclamation. Appl. Soil Ecol. 2020, 156, 103699. [CrossRef]

49. Grządziel, J.; Furtak, K.; Gałązka, A. Community-level physiological profiles of microorganisms from different types of soils that are characteristic to Poland-a long term microplot experiment. Sustainability 2019, 11, 56. [CrossRef]

50. Czerwonka, G.; Konieczna, I.; Żarnowiec, P.; Zieliński, A.; Malinowska-Gniewosz, A.; Gałuszka, A.; Migaszewski, Z.; Szarlip, P. Characterization of microbial communities in acidified, Sulphur containing soils. Pol. J. Microbiol. 2017, 66, 509-517. [CrossRef]

51. Wolińska, A.; Górniak, D.; Zielenkiewicz, U.; Goryluk-Salmonowicz, A.; Kuźniar, A.; Stępniewska, Z.; Błaszczyk, M. Microbial biodiversity in arable soils is affected by agricultural practices. Int. Agrophysics 2017, 31, 259-271. [CrossRef]

52. Minasny, B.; Hong, S.Y.; Hartemink, A.E.; Kim, Y.H.; Kang, S.S. Soil pH increase under paddy in South Korea between 2000 and 2012. Agric. Ecosyst. Environ. 2016, 221, 205-213. [CrossRef]

53. Neina, D. The Role of Soil pH in Plant Nutrition and Soil Remediation. Appl. Environ. Soil Sci. 2019, 2019, 9. [CrossRef]

54. Sinsabaugh, R.L.; Lauber, C.L.; Weintraub, M.N.; Ahmed, B.; Allison, S.D.; Crenshaw, C.; Contosta, A.R.; Cusack, D.; Frey, S.; Gallo, M.E.; et al. Stoichiometry of soil enzyme activity at global scale. Ecol. Lett. 2008, 11, 1252-1264. [CrossRef]

55. Pawar, R.M. The effect of soil $\mathrm{pH}$ on bioremediation of polycyclic aromatic hydrocarbons (PAHS). J. Bioremediation Biodegrad. 2015, 6, 291-304. [CrossRef]

56. Husson, $\mathrm{O}$. Redox potential (Eh) and $\mathrm{pH}$ as drivers of soil/plant/microorganism systems: A transdisciplinary overview pointing to integrative opportunities for agronomy. Plant Soil 2012, 362, 389-417. [CrossRef]

57. Błońska, E. Enzyme activity in forest peat soils. Folia For. Pol. 2010, 52, 20.

58. Brzezińska, M.; Stępniewska, Z.; Stępniewski, W. Soil oxygen status and dehydrogenase activity. Soil Biol. Biochem. 1998, $30,1783$. [CrossRef]

59. Włodarczyk, T. Some aspects of dehydrogenase activity in soils. Int. Agrophysics 2000, 14, 365-376.

60. Wu, C.S.; Liu, G.H.; Ma, G.X.; Liu, Q.S.; Yu, F.; Huang, C.; Zhao, Z.; Liang, L. Study of the differences in soil properties between the dry season and rainy season in the Mun River basin. Catena 2019, 182, 104103. [CrossRef]

61. Upton, R.N.; Bach, E.M.; Hofmockel, K.S. Spatio-temporal microbial community dynamics within soil aggregates. Soil Biol. Biochem. 2019, 132, 58-68. [CrossRef] 
62. Zhang, P.; Cui, Z.; Guo, M.; Xi, R. Characteristics of the soil microbial community in the forestland of Camellia oleifera. PeerJ 2019, 8, e9117. [CrossRef]

63. Wolińska, A.; Włodarczyk, K.; Kuźniar, A.; Marzec-Grządziel, A.; Grządziel, J.; Gałązka, A.; Uzarowicz, Ł. Soil Microbial Community Profiling and Bacterial Metabolic Activity of Technosols as an Effect of Soil Properties following Land Reclamation: A Case Study from the Abandoned Iron Sulphide and Uranium Mine in Rudki (South-Central Poland). Agronomy 2020, 10, 1795. [CrossRef]

64. Sadaf, K.; Anirban, B.; Iqbal, A.; Sayyed, R.Z.; El-Enshasy, H.A.; Dailin, D.J.; Suriani, N.L. Recent Understanding of Soil Acidobacteria and Their Ecological Significance: A Critical Review. Front. Microbiol. 2020, 11, 2712.

65. Männistö, M.K.; Tiirola, M.; Haggblom, M.M. Bacterial communities in Arctic fields of Finnish Lapland are stable but highly pH-dependent. FEMS Microbiol. Ecol. 2007, 59, 452-465. [CrossRef] [PubMed]

66. Lladó, S.; López-Mondéjar, R.; Baldrian, P. Drivers of microbial community structure in forest soils. Appl. Microbiol. Biotechnol. 2018, 102, 4331-4338. [CrossRef] [PubMed]

67. Wolińska, A.; Kuźniar, A.; Zielenkiewicz, U.; Banach, A.; Błaszczyk, M. Indicators of arable soils fatigue-Bacterial families and genera: A metagenomic approach. Ecol. Indic. 2018, 93, 490-500. [CrossRef]

68. Wolińska, A. Metagenomic Achievements in Microbial Diversity Determination in Croplands: A Review. In Microbial Diversity in the Genomic Era; Academic Press: Cambridge, MA, USA, 2019; Volume 2, pp. 15-35.

69. Xiao, X.M.; Cheng, Z.H.; Meng, H.W.; Liu, L.H.; Li, H.Z.; Dong, Y.X. Intercropping of green garlic (Allium sativum L.) induces nutrient concentration changes in the soil and plants in continuously cropped cucumber (Cucumis sativus L.) in a plastic tunnel. PLoS ONE 2013, 8, 62173. [CrossRef] [PubMed]

70. Zhou, X.; Yu, G.; Wu, F. Effects of intercropping cucumber with onion or garlic on soil enzyme activities, microbial communities and cucumber yield. Eur. J. Soil Biol. 2011, 47, 279-287. [CrossRef]

71. Bargaz, A.; Noyce, G.L.; Fulthorpe, R.; Carlsson, G.; Furze, J.R.; Jensen, E.S.; Dhiba, D.; Isaac, M.E. Species interactions enhance root allocation, microbial diversity and $\mathrm{P}$ acquisition in intercropped wheat and soybean under P deficiency. Appl. Soil Ecol. 2017, 120, 179-188. [CrossRef]

72. Wang, G.; Bei, S.; Li, J.; Bao, X.; Zhang, J.; Schultz, P.A.; Li, H.; Li, L.; Zhang, F.; Bever, J.D.; et al. Soil microbial legacy drives crop diversity advantage: Linking ecological plant-soil feedback with agricultural intercropping. J. Appl. Ecol. 2020, $186,281$. [CrossRef]

73. Dang, K.; Gong, X.; Zhao, G.; Wang, H.; Ivanistau, A.; Feng, B. Intercropping alters the soil microbial diversity and community to facilitate Nitrogen assimilation: A potential mechanism for increasing pros millet grain yield. Front. Microbiol. 2020, 11, 2975. [CrossRef]

74. Li, Q.; Chen, J.; Wu, L.; Luo, X.; Li, N.; Arafat, Y.; Lin, S.; Lin, W. Belowground Interactions Impact the Soil Bacterial Community, Soil Fertility, and Crop Yield in Maize/Peanut Intercropping Systems. Int. J. Mol. Sci. 2018, 19, 622. [CrossRef]

75. Correa-Galeote, D.; Bedmar, E.J.; Arone, G.J. Maize endophytic bacterial diversity as affected by soil cultivation history. Front. Microbiol. 2018, 9, 484. [CrossRef]

76. Liu, Y.; Zuo, S.; Xu, L.; Zou, Y.; Song, W. Study on diversity of endophytic bacterial communities in seeds of hybrid maize and their parental lines. Arch. Microbiol. 2012, 194, 1001-1012. [CrossRef] [PubMed] 